\title{
Çevre-Enerji Konularına Yönelik Gerçekleştirilen Argümantasyon Temelli Öğretimin Sınıf Öğretmeni Adaylarının Argüman Oluşturabilmelerine Etkisi*
}

\author{
The Effect of Argumentation-Based Teaching Carried out for \\ Environment-Energy Subjects on The Argumentation Skills of \\ Prospective Teacher \\ Hamdi KARAKAȘ ${ }^{1}$ Rabia SARIKAYA ${ }^{2}$
}

• Geliş Tarihi: 08.02.2019 • Kabul Tarihi: 24.07.2019 • Çevrimiçi Yayın Tarihi: 24.07.2019

\section{$\ddot{O} \mathbf{z}$}

$\mathrm{Bu}$ çalışmanın amacı, çevre-enerji konularına yönelik gerçekleştirilen argümantasyon temelli öğretimin sınıf öğretmeni adaylarının argüman oluşturma becerilerine etkisini incelemektir. Araştırmada bütüncül çoklu durum deseni kullanılmıştır. Ölçüt örnekleme yöntemiyle belirlenen çalışma grubu, sınıf öğretmenliği ikinci sınıfta okuyan ve "Çevre Eğitimi" dersini alan 44 öğretmen adayından oluşmaktadır. Argümantasyon temelli öğretim sürecinde, sosyobilimsel yapıda olan çevre-enerji konularında hazırlanan senaryolar kullanılmıştır. Verilerin analizinde doküman analizi kullanılmış, adayların bireysel ve grup olarak oluşturdukları argümanlar Toulmin Argüman Modeli esas alınarak değerlendirilmiş ve "Argüman Yapısı Puanlama Anahtarı'na" göre argüman ortalama puanları, "Argümantasyon Değerlendirme Ölçeği’ne" göre de argüman düzeyleri belirlenmiştir. Araştırma sonucunda, argümantasyon temelli öğretim süreci boyunca sınıf öğretmeni adaylarının bireysel, grup, bireysel karşıt ve grup karşı argüman oluşturma ortalama puanlarında ilk etkinlikten son etkinliğe doğru bir artışın olduğu, ortalama puanlar arası farkın da istatiksel olarak anlamlı olduğu $(\mathrm{p}<0,05)$ tespit edilmiştir. Bireysel ve bireysel karşıt argüman ortalama puanlar arası farkın etki büyüklüğü (Cohen's $f$ ) de "geniş etki” olarak tespit edilmiştir. Aynı zamanda argüman düzeyleri süreç boyunca ilk haftadan son haftaya doğru orta ve yüksek düzeye doğru ilerleme göstermiştir. Ancak sınıf öğretmeni adaylarının oluşturdukları bireysel karşıt argümanlardaki ilerleyişin yeterli seviyede olmadığı görülmüştür. Süreç ilerledikçe ortalama puanların ve argüman düzeylerinin artışı sınıf öğretmeni adaylarının daha nitelikli argüman ürettiklerinin bir göstergesidir.

Anahtar sözcükler: argümantasyon seviyesi, argümantasyon temelli öğretim, sosyobilimsel konular, sınıf öğretmeni adayları

Atıf:

Karakaş, H. ve Sarıkaya R. (2020). Çevre-enerji konularına yönelik gerçekleştirilen argümantasyon temelli öğretimin sınıf öğretmeni adaylarının argüman oluşturabilmelerine etkisi. Pamukkale Üniversitesi Eğitim Fakültesi Dergisi, 48, 346-373.doi:10.9779/pauefd.524850

\footnotetext{
* Bu çalışma ikinci yazarın danışmanlığında tamamlanmış, birinci yazarın doktora tezinin bir bölümüdür.

1 Dr. Öğretim Üyesi, Sivas Cumhuriyet Üniversitesi, Eğitim Fakültesi, Eğitim Bilimleri Bölümü, hamdikarakas58@yahoo.com.tr ORCID: 0000-0001-9209-4128

2 Prof. Dr., Gazi Üniversitesi, Gazi Eğitim Fakültesi, Temel Eğitim Bölümü, rabiasarikaya@gmail.com ORCID: 0000-0001-9247-8973
} 
Öğretmeni Adaylarının Argüman Oluşturabilmelerine Etkisi

\begin{abstract}
The aim of this research is to investigate the effect of argumentation-based teaching carried out for environmentenergy subjects on argumentation skills of classroom teacher candidates. The research was conducted in accordance with the multiple holistic case study. The study group, which was determined by criterion sampling method, consisted of 44 pre-service teachers studying in the second grade and taking the Environmental Education course. In the argumentation-based teaching process, the scenarios prepared on environmental-energy issues in the socio-scientific structure were used. In the analysis of data, the candidates' individual and grouped arguments were evaluated according to the Toulmin Argument Model; argument average scores were determined according to "Argument Structure Scoring Key", argument levels were determined according to "Argumentation Evaluation Scale". As a result of the research, an increase in the average scores for formation of individual/group, individual and group counter arguments by the classroom teacher candidates from the first activity to the last one was detected and a difference between the mean scores was statistically significant ( $\mathrm{p}<0.05)$. The effect size of the difference between the individual and individual counter-argument average scores (Cohen's $f$ ) was determined as "wide effect". At the same time, the argument levels progressed from the first week to the last week to the middle and high levels throughout the process. However, it was observed that the progress in the individual counter arguments of the class teacher candidates was not sufficient. As the process progresses, the increase of average scores and argument levels is an indication of the fact that class teacher candidates produce more qualified arguments.
\end{abstract}

Keywords: argumentation level, argumentation-based teaching process, socio-scientific subjects, prospective teacher

\title{
Cited:
}

Karakaş, H. \& Sarıkaya, R. (2020). The effect of argumentation-based teaching carried out for environment-energy on the argumentatin skills of prospective teacher. Pamukkale Üniversitesi Eğitim Fakültesi Dergisi, 48, 346-373. doi:10.9779/pauefd.524850 


\section{Giriş}

Günümüzde fen eğitimden beklenen öğrencilerin ezbere dayalı bilgilerle donatılması değil; elde ettikleri bilgileri sorgulayan, bu bilgileri farklı durumlarda ve problem çözümlerinde işlevsel bir şekilde kullanabilen bireyler yetiştirmeyi sağlamaktır (Aktaş, 2017). Beklenen öğrenci modelini yetiştirebilmek için etraflarındaki doğal ve fiziksel dünyayı keşfetme isteği duyarak araştırabildikleri, sorgulayabildikleri, tartışabildikleri ve bir bilim insanı gibi düşünerek bilgiyi kendi zihinlerinde oluşturdukları yöntem ve stratejiler öğrenme-öğretme süreçlerine dâhil edilmelidir (Babacan, 2017). Gray ve Bryce (2006), öğrencilerin medyada ya da günlük yaşamda karşılaştıkları gelişmelerle ilgili konularda bilinçli yargılarda ve kararlarda bulunabilmeleri için gerekli temel alt yapı ve becerilere sahip olmaları gerektiğini, dolayısıyla toplumsal, ahlaki ve etik konuların yer aldığı sosyobilimsel konuların fen eğitiminin her aşamasına dâhil edilmesi fikrini savunmuşlardır. Sosyobilimsel konular, bilimsel bir yanı olmasına rağmen bilimsel bilginin sınırlarında, bireysel veya toplumsal anlamda karar gerektiren, karmaşık, açık-uçlu, çoğunlukla tartışmalı ve ikilemli konular olarak tanımlanır (Kolsto, 2010; Sadler, 2003). Sosyobilimsel konular, zorunlu olarak iki sonucu olan ve her iki seçenekten birini tercih etmeye zorlayan ikilemleri kapsar (Karakaya, 2015). Sosyobilimsel temelli öğretim yapmak, sıkıcı ve öğrencilerin ilgi göstermediği bilimsel içerikli konuları daha ilginç ve hoşnut hale getirir (Dolan, Nichols \& Zeidler, 2009). National Research Council (NRC) tarafından 1996 yılında yayınlanan Ulusal Fen Eğitimi Standartları'nda sosyobilimsel konuların öğrencilerce tartışılmasını, analiz edilmesini ve okul programlarında yer almasını savunmaktadır (Topçu, 2015). Çünkü, sosyobilimsel durumları tartışırken öğrenciler aktif düşünme içinde bulunacak, olayları yorumlayacak, argüman geliştirecek ve uygulamaya dönük fikirler sunacaktır.

Enerji konusu, temel bir ihtiyaç olarak değerlendirilmesinin yanı sıra çevreye olan etkileri bakımından değerlendirilen sosyobilimsel bir konudur. Enerji talebinin artması, insan hayatının kolaylaştırılması ve ülkelerin kalkınması açısından önemli olan enerji, üretiminden tüketimine kadar oluşturduğu bölgesel ve küresel felaketlerle ekolojik yapının değişmesine yol açar. Ayrıca toplumun ihtiyaç duyduğu enerjiyi doğayla uyumlu olarak sunmak ve farklı enerji kaynaklarını kullanarak enerji çeşitliliğini arttırmak hem bugün hem de yarın için önemli görülür (İpekoğlu vd., 2014). Yakın gelecekte mevcut enerji kaynaklarının insanların ihtiyaçlarını karşılayamayacak olma algısı, enerjinin fen eğitimi açısından değerlendirilmesini kaçınılmaz hale getirmiş, sürekli kendisini yenileyen ve tükenmeyen yenilenebilir enerji kaynaklarının eğitim ve öğretimine müfredat programlarında yer verilmeye başlanmıştır (Aslan, 2015).

Okullarda sosyobilimsel temelli yapılacak öğretim etkinleri ile öğrenciler, fen bilimleri dersi ile bilimsel ve teknolojik gelişmelerin çevre ve toplumu ne şekilde etkilediğini bilimsel çerçevede yorumlayabileceklerdir. Öğrencilerin bu bilimsel çerçevede sosyobilimsel konuları tartışabilecekleri bir yöntem de argüman üretme sürecidir. Argüman bir tartışma sürecine katkıda bulunan iddialar, veriler, gerekçeler ve destekleyiciler olarak tanımlanmakta (Erduran, Simon \& Osborne, 2004); bir durumun veya konunun güçlü yönlerini ortaya sunma ve diğerlerini bu fikre ikna etmek için ileri sürülen ifadeler olarak nitelendirilmektedir (Güzel, Erduran ve Ardaç, 2009). Böylece birey kendi düşünme sürecinde açıklamalarını ve kanıtlarını organize biçimde analiz ederek, bilimsel tartışma sürecinde hem bilişsel hem de sosyal bir 
argümantasyon sürecine dâhil olur (Duschl \& Osborne, 2002). Argümantasyon sürecinde öğrenciler, farklı fikirler arasında verilere dayalı ortak bir düşünceye ulaşma gayreti içerisinde olurlar (Furtak, 2006). Sınıflarda argüman oluşturma temelli bir ortam oluşturarak öğrencilerin birbirlerine sorular sormaları teşvik edilir. Öğrencilerden ortaya atılan fikirler hakkında yorum yapabilmeleri, sonuçları bilimsel olarak değerlendirmeleri ve açıklamaları analiz edebilmeleri istenir (Çınar, 2016). Argümantasyonun öğrenme sürecine dahil edildiği sınıf içi tartışmalarında, fikirler üretmeye dayalı ve elde edilen farklı fikirlerin kanıtlar doğrultusunda değerlendirilip en iyi düşünceyi ortaya çıaran argümantasyonun seçilmesi şeklinde ders süreci daha verimli hale gelmektedir (Aktaş, 2017).

Toulmin (1958) bireylerin davranışlarını, inanışlarını, tutumlarını ve değerlerini haklı çıkarmak ve karşısındaki insanları ikna etmek için neden veya gerekçe sunarak argüman ürettiklerini ifade eder. Ancak bireylerin aynı durum, problem veya konu ile ilgili oluşturdukları argümanların birbirinden farklı olabileceğini savunmuştur. Oluşturduğu "Toulmin Argüman Modeline" göre veri, iddia ve gerekçe argümanın temel bileşenleri olarak belirlemiş, daha karmaşık argümanlar için bu modele destekleyici, niteleyici (sınırlayıc1) ve çürütücü bileşenler dahil etmiştir (Aldağ, 2006). Bu modelin öğrenme-öğretme ortamlarında kullanılması ile teori ve öğrenme modelleri özel bir alanda bir araya getirilirken, iddia, veri veya gerçek dünya deneyimlerini kullanarak öğrenciler kendini ifade ederler. Böylece olası problemlere çözümler üretmelerini sağlayan sosyal bir etkinlik olarak süreç içerisinde kullanılır (Andrews, 2010).

Argümantasyon yöntemi konuların daha ilginç bir şekilde öğretilmesini, öğrenilen bilginin hatırlanmasını, bilginin daha kalıcı öğrenilmesini, analiz ve sentez yapılmasını geliştirmesi açısından öğrenciler için önemli bir öğretim metodudur (Schmoker \& Graff, 2011). $\mathrm{Bu}$ da ancak argümantasyon sürecine ilişkin deneyim kazanma ve Toulmin Argüman Modeline ait bileşenlerini kullanarak argüman kalitesini arttırmakla mümkün olabilir. Dolayısıyla bu yönteme ilişkin deneyim kazanmak, argüman bileşenlerinin nerede ve nasıl kullanabileceğin yönelik uygulamalarda aktif olarak yer almak argümantasyon sürecinde istenilen hedeflere ulaşmada yararlı olacaktır. Bu noktada gelecekte ilk kez fen konularıyla öğrencileri tanıştıracak olan sınıf öğretmeni adaylarının argümantasyon temelli öğretim süreci ile ilgili deneyim kazanmaları araştırmacılarca önemli görülmüştür. Argümantasyon temelli öğretim sürecini çevre-enerji konularını bir araç olarak kullanan, bu sayede argüman oluşturma becerisini hem ortalama puanlar hem de düzey olarak ölçen ve özellikle de çalışma grubu sınıf öğretmeni adaylarından oluşan bir çalışmaya literatürde rastlanamamıştır. Bu araştırma ile argümantasyon sürecinde çevre-enerji konularındaki sosyobilimsel durumlar irdelenerek sınıf ögretmeni adayları öğrenmenin merkezine alınmıştır. Süreç boyunca sınıf öğretmeni adaylarının argüman bileşenlerini kullanabilmeleri ve böylece argüman kalitelerini ortalama puan ve düzey olarak arttırabilmeleri araştırılmıştır. Aynı zamanda sınıf öğretmeni adaylarının çağdaş bir öğretim sürecinde yer alması hem mesleğe hazırlanması hem de yeni gelen nesli yetiştirmesi noktasında önemli görülmüş ve literatüre katkı sağlayacağı düşünülmüştür. Bu bağlamda çalışmanın amacı, çevre-enerji konularına yönelik gerçekleştirilen argümantasyon temelli öğretimin sınıf öğretmeni adaylarının argüman oluşturma becerilerine etkisini incelemektir. $\mathrm{Bu}$ amaç doğrultusunda araştırmanın temel problem cümlesi; "Çevre-enerji konularına yönelik gerçekleştirilen argümantasyon temelli öğretimin sınıf öğretmeni adaylarının argüman oluşturma becerilerine etkisi nasıldır?" şeklinde belirlenmiştir. Temel problem cümlesi bağlamında oluşturulan alt problemler aşağıda sıralanmıştır: 
1. Argümantasyon temelli öğretim sürecinin uygulandığı on farklı etkinlik sonunda sınıf öğretmeni adaylarının argüman oluşturma ortalama puanları arasında anlamlı fark var midir?

1.1. Sınıf öğretmeni adaylarının bireysel argüman oluşturma ortalama puanları arasında anlamlı bir fark var mıdır?

1.2. Sınıf öğretmeni adaylarının grup argümanı oluşturma ortalama puanları arasında anlamlı bir fark var midir?

1.3. Sınıf öğretmeni adaylarının bireysel karşıt argüman oluşturma ortalama puanları arasında anlamlı bir fark var midir?

1.4. Sınıf öğretmeni adaylarının grup karşıt argüman oluşturma ortalama puanları arasında anlamlı bir fark var midir?

2. Argümantasyon temelli öğretim sürecinin uygulandığı on farklı etkinlik sonunda sınıf öğretmeni adaylarının argüman oluşturma düzeyleri nasıl değişmiştir?

2.1. Sınıf öğretmeni adaylarının bireysel argüman oluşturma düzeyleri nasıl değişmiştir?

2.2. Sınıf öğretmeni adaylarının grup argümanı oluşturma düzeyleri nasıl değişmiş̧tir?

2.3. Sınıf öğretmeni adaylarının bireysel karşıt argüman oluşturma düzeyleri nasıl değişmiştir?

2.4. Sınıf öğretmeni adaylarının grup karşıt argüman oluşturma düzeyleri nasıl değişmiş̧ir?

\section{Yöntem}

\section{Araştırma Modeli}

Araştırmada durum çalışması türlerinden bütüncül çoklu durum deseni kullanılmıştır. Durum çalışması, araştırmacının zaman içerisinde sınırlandırılmış çoklu kaynakları içeren, gözlem, görüşme, doküman, vb. veri toplama araçları kullanarak durumları derinlemesine incelediği, duruma bağlı temaların tanımlandığı araştırma yaklaşımıdır (Creswell, 2013). Bütüncül çoklu durum deseninin kullanıldığı bu çalışmada incelenen "çoklu durum" sınıf öğretmeni adaylarının hazırlanan senaryolar doğrultusunda çevre-enerji konularının alt bileşenlerine yönelik argüman oluşturmaları ve daha sonra süreç içerisinde analiz edilen verilerin karşılaştırılmasıdır. Argümantasyon temelli öğretim süreci sonunda sınıf öğretmeni adaylarının çevre-enerji konularına yönelik senaryolara vermiş oldukları bireysel ve grup argümanları analiz edilip, veriler yorumlanmıştır. Senaryolara ilişkin argümanlar sınıf ortamında yazılı olarak elde edilmiş ve elde edilen bu dökümanlar analiz edilmiştir.

\section{Uygulama Süreci}

Araştırmacılar, çevre eğitimi dersinde argümantasyon temelli öğretim uygulamışlardır. Araştırmacı her hafta çevre eğitimi ders konuları hakkında bilgi vermiş, konuları görsel ve işitsel araçlarla destekleyerek soru-cevap yöntemini de kullanarak dersleri işlemiştir. Her hafta ders konuları bittikten sonra kalan sürede sınıf öğretmeni adaylarından çevre-enerji konularına yönelik argüman oluşturmaları istenmiştir. Hazırlanan senaryoların isimleri ve ilişkili oldukları konular Tablo 2'de sunulmuştur. 
Öğretmeni Adaylarının Argüman Oluşturabilmelerine Etkisi

Tablo 2. Hazırlanan Senaryolara İlişkin Bilgiler

\begin{tabular}{|c|c|c|}
\hline Hafta & Senaryo Adı & Senaryo Konusu \\
\hline 1 & Hidrolik Enerji & $\begin{array}{l}\text { Hidrolik güç kullanımı, Hidroelektrik Santralleri (HES) ve Dalga } \\
\text { enerji santrallerinin kullanım, çevreye etkileri, ekonomik } \\
\text { yansımaları. }\end{array}$ \\
\hline 2 & Elektrikli Otomobil & $\begin{array}{l}\text { Elektrikli ve benzinli araçların çalışma prensibi, kullanım, } \\
\text { performans, çevreye etkileri ve ekonomik yansımaları noktasında } \\
\text { karşılaştırılması. }\end{array}$ \\
\hline 3 & Paris İklim Değişikliği & $\begin{array}{l}\text { Fosil yakıt kullanımı, sera gazlarının artışı, küresel ısınma, alınan } \\
\text { tedbirler ve çevresel ve ekonomik yansımaları. }\end{array}$ \\
\hline 4 & Biyo-yakut Üretimi & $\begin{array}{l}\text { Biyo-yakıt üretim yöntemleri, kullanımı, sınırlılıkları ve tarım } \\
\text { sektörüne yönelik tehtidler. }\end{array}$ \\
\hline 5 & Nükleer Enerji & $\begin{array}{l}\text { Nükleer enerji ve üretim yöntemleri, nükleer enerji santralleri, } \\
\text { atıklar, çevresel ve ekonomik yansımaları. }\end{array}$ \\
\hline 6 & Rüzgâr Enerjisi & $\begin{array}{l}\text { Rüzgar Enerji Santralleri (RES), işlevselliği, çevresel ve ekonomik } \\
\text { yansımaları. }\end{array}$ \\
\hline 7 & Güneş Enerjisi & $\begin{array}{l}\text { Güneş Enerji Santralleri (GES), işlevselliği, çevresel ve ekonomik } \\
\text { yansımaları. }\end{array}$ \\
\hline 8 & Sicak Çermik & $\begin{array}{l}\text { Jeotermal enerji, kullanımı, turizm sektörü ile karşılaştırılması, } \\
\text { çevresel ve ekonomik yansımaları. }\end{array}$ \\
\hline 9 & Hidrojen Enerjisi & $\begin{array}{l}\text { Hidrojen enerjisi üretim yöntemleri, kullanım alanları, } \\
\text { sinırlılıkları, çevresel ve ekonomik yansımaları. }\end{array}$ \\
\hline 10 & Enerjinin Geleceği & $\begin{array}{l}\text { Enerji kaynaklarının çeşitliliği ve öğretmen adaylarınca tercih } \\
\text { edilen kaynakların gerekçeleri. }\end{array}$ \\
\hline
\end{tabular}

$\mathrm{Bu}$ süreçte ilk önce çevre-enerji ilişkisini yansıtan senaryo formu dağıtılmış ve sınıf öğretmeni adaylarından o haftaki senaryoyu okuyarak bireysel formlara oluşturdukları bireysel argüman ve bireysel karşıt argümanlarını yazmaları istenmiştir. Araştırmacı bu noktada rehber rolünü üstlenmiş, sınıf içerisinde dolaşarak senaryolarla ilgili bilimsel soruları cevaplamış ve adayların argüman oluştururken iddialarını geçerli kanıtlarla desteklemeleri ve daha yüksek kalitede argümanlar oluşturmaları yönünde telkinde bulunmuştur. Bu süreç yaklaşık 20 dakika sürmüştür. Daha sonra çalışma grubundaki öğretmen adayları heterojen gruplara ayrılarak her gruba aynı senaryonun yer aldığı grup formları dağıtılmıştır. Her gruptan bireysel ve bireysel karşıt argümanların tartışılması istenmiştir. Tartışma süreci sonunda gruplar aynı senaryoya yönelik oluşturdukları grup argümanı ve grup karşıt argümanlarını grup formlarına yazmışlardır. Araştırmacı bu sırada rehber rolü üstlenerek sınıf içerisinde dolaşarak grupları ziyaret etmiştir. $\mathrm{Bu}$ süreç de yaklaşık 20 dakika sürmüştür. Araştırmacı her bir sınıf öğretmeni adayının bireysel formlarını ve her bir grubun grup formalarını toplayarak derse son vermiştir. Bu uygulama süreci bir akademik dönem ders süreci içerisinde 10 hafta boyunca devam etmiştir.

\section{Çalışma Grubu}

Ölçüt örnekleme yöntemiyle 2017-2018 akademik yılı güz döneminde İç Anadolu Bölgesindeki bir üniversitenin Eğitim Fakültesi Temel Eğitim Bölümü Sınıf Eğitimi Ana Bilim Dalı ikinci sınıfta okuyan 44 öğretmen adayı çalışma grubuna dahil edilmiştir. Araştırmanın çalışma grubunu belirlemede kullanılan ölçüt; sınıf öğretmeni adaylarının çevre eğitimi dersi alıyor olmaları şeklinde belirlenmiştir. Çevre eğitimi dersinin bir ölçüt olarak belirlenme nedeni, ders içeriğinin çevre ve enerji konularında farkındalık sağlaması ve argümantasyon temelli öğretime uygun olmasıdır. Grup argümanı oluşturma süreci için çalışma grubundan heterojen tartışma 
grupları oluşturulmuştur. $\mathrm{Bu}$ çalışma gruplarının oluşturulması amacıyla uygulama süreci öncesi "Watson-Glaser Eleştirel Akıl Yürütme Ölçeği" ve "Enerji Başarı Testi" uygulanmıştır. Öğretmen adayları bu testlerden aldıkları ortalama puanlar ve cinsiyet değişkeni dikkate alınarak heterojen olarak beşerli ve altışarlı argüman gruplarına ayrılmışlardır.

\section{Veri Toplama Aracı}

$\mathrm{Bu}$ çalışmada sınıf öğretmeni adaylarının argümantasyon becerilerini tespit etmek amacıyla araştırmacılar tarafından çevre-enerji konularına yönelik, enerji kaynaklarını ve çeşitlerini, enerjinin üretilmesini ve kullanılmasını, çevre-enerji-kalkınma ilişkisini irdeleyen, gerçek yaşam problemlerini içeren, sosyobilimsel senaryolar hazırlanmıştır. Senaryoların hazırlanma sürecinde sınıf öğretmeni adaylarının çevre-enerji ilişkisini sorgulayabilecekleri, konu hakkında veri, iddia, gerekçe, destekleyici ve çürütücü ileri sürebilecekleri, öğrencileri ikileme düşürecek ve karar vermelerini gerektirecek durumlardan yararlanılmıştır. Senaryolarda çevre-enerji ilişkisini ortaya koyan, durumlar hakkında bilimsel bilgilerin yer aldığı ve adayları ikilemlere düşüren durumlara yer verilmiştir. Senaryolarda çevre-enerji konularına yönelik alan bilgisine yer verilmesi gerekliliği Alexander, Kulikowich ve Schulze (1994) argümantasyon becerilerinin geliştirilmesine yönelik çalışmasında vurgulanarak, bireylerin argüman oluşturabilmeleri için konu hakkında alan bilgisine sahip olunması gerektiği savunulmuştur. Khishfe (2012), bir konu hakkında ön bilgilere sahip olan öğrencilerin argümantasyon sürecine daha etkin olarak katıldıklarını ve argümanlarını doğru biçimde yapılandırdıklarını belirtmektedir.

$\mathrm{Bu}$ araştırmada araştırmacılar tarafından 10 farklı senaryo hazırlanmıştır. Bu senaryolar Çevre Eğitimi konularında çalışmaları olan iki Sınıf Eğitimi Ana Bilim Dalı öğretim üyesine ve bir Eğitim Bilimleri Ana Bilim Dalı öğretim üyesine uzman görüşü almak üzere gönderilmiştir. Uzmanlar senaryoları amaca uygunluk, ifadelerin açıklı̆̆ı, kapsam geçerliliği yönünden değerlendirerek görüş bildirmişlerdir. Uzman görüşleri doğrultusunda hazırlanan 4, 5 ve 9 numaralı senaryolar amaca uygunluk bakımından yeniden düzenlenmiştir. Tüm senaryolar bir dil uzmanı ile birlikte tekrar kontrol edilmiş ve gerekli düzenlemeler yapılmıştır. Senaryoların amaca uygunluğunu test etmek için örneklem grubuna dahil olmayan sınıf öğretmeni adaylarıyla üç haftalık ( 6 ders saati) bir ön uygulama yapılmış ve sonrasında senaryolar son şeklini almıştır. Asıl uygulamada kullanılacak olan 10 senaryo enerji kaynaklarının ülkemizde yaygın kullanımı ve konunun kamuoyunda tartışılma özelliğine göre araştırmacılar tarafından sıralanarak her hafta hangi senaryonun kullanılacağı belirlenmiştir.

\section{Verilerin Analizi}

Verilerin analizinde doküman analizi kullanılmış olup adayların bireysel ve grup olarak her bir senaryo için oluşturdukları argümanlar, Toulmin Argüman Modeli temel alınarak değerlendirilmiştir. Sınıf öğretmeni adaylarının argüman oluşturma ortalama puanlarının hesaplanmasında "Argüman Yapısı Puanlama Anahtarı" kullanılmış, argüman düzeylerinin belirlenmesinde ise "Argümantasyon Değerlendirme Ölçeği” kullanılmıştır.

Argüman Yapısı Puanlama Anahtarı, Şahin (2014) tarafından geliştirilmiş ve Toulmin Argüman Modelin'deki boyutlara göre oluşturulmuştur. Öğretmen adaylarının oluşturdukları argümanlar, argüman bileşenlerinin (iddia, veri, gerekçe, destekleyici ve çürütücü) varlığı ve 
Öğretmeni Adaylarının Argüman Oluşturabilmelerine Etkisi

bileşenlerin net/güçlü olmasına göre puanlar almaktadır. Bu çalışmada da uzman görüşü doğrultusunda Argüman Yapısı Puanlama Anahtarı üzerinde düzenlemeler yapılmış ve anahtara son hali verilmiştir. Öğretmen adayları, oluşturdukları argümanlardan en az 1, en fazla 9 puan almakta ve puanların azlığı ya da çokluğu argüman kalitesinin düşüklüğü ya da yüksekliğini ifade etmektedir. Bu anahtar, adaylardan alıntı örnekleri verilerek Tablo 2'de sunulmuştur.

Tablo 2. Argüman Yapısı Puanlama Anahtarı

\begin{tabular}{|c|c|c|c|}
\hline Boyutlar & Alt Boyutlar & Açıklama / Örnek & Puan \\
\hline \multirow{3}{*}{ 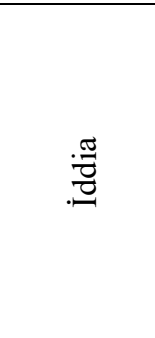 } & Mevcut & $\begin{array}{l}\text { İddia cümlesinin net olarak bulunur. } \\
\text { Ör: Biyodizel yakıtlar kullanılmalıdır. ... (E-3, D-38) }\end{array}$ & 2 \\
\hline & Kismen Mevcut & $\begin{array}{l}\text { İddia cümlesi net olarak bulunmaz ancak cümle yapısından } \\
\text { iddianın desteklendiği veya desteklenmediği anlaşılır. } \\
\text { Ör: Biyodizel kullanımılyla bölgedeki meyve-sebze fiyat } \\
\text { artışlart yaşanır. ... (E-3,D-27) }\end{array}$ & 1 \\
\hline & Yok & $\begin{array}{l}\text { İddia cümlesi bulunmaz. } \\
\text { Ör: - }\end{array}$ & 0 \\
\hline \multirow{4}{*}{$\frac{\circlearrowright}{\mathscr{U}}$} & $\begin{array}{l}\text { Çok Bilimsel } \\
\text { Açıklama / Veri / } \\
\text { Terim }\end{array}$ & $\begin{array}{l}\text { Birden fazla bilimsel açıklama, veri veya terim kullanır. } \\
\text { Ör: ... fosil yakıtların zamanla tükenmesi nükleer enerji } \\
\text { kullanımını ön plana çıkartmaktadır. ... sera gazı salınımı } \\
\text { yapmaması hava kirliliğ } \breve{i} \text { açısından önemlidir. ... Dünya } \\
\text { üzerinde bir çok ülke enerji ihtiyacını nükleer enerjiden } \\
\text { kazanarak dışa bağımlılığını azaltmıştır. (E-5, D-16) }\end{array}$ & 3 \\
\hline & $\begin{array}{c}\text { Bilimsel } \\
\text { Açıklama / Veri / } \\
\text { Terim } \\
\end{array}$ & $\begin{array}{l}\text { Bir bilimsel açıklama, veri veya terim kullanır. } \\
\text { Ör: ... nükleer enerji santrali } \mathrm{CO}_{2} \text { salınımı yapmayarak } \\
\text { atmosferdeki sera gazları azalacaktır. ... (E-5, D-35) }\end{array}$ & 2 \\
\hline & Genel Açıklama & $\begin{array}{l}\text { Bilimsel bir açıklama, veri veya terim kullanmaz. Genel } \\
\text { açılama yapar. } \\
\text { Orr... nükleer enerji santralleri diğer santrallere göre daha } \\
\text { az yer kaplar. ... (E-5,D-15) }\end{array}$ & 1 \\
\hline & Kavram Yanılgisı & $\begin{array}{l}\text { Kavramları yanlış ifade eder ya da kullanır. } \\
\text { Orr: ... nükleer reaktörlerden çıkan gazın hava kirliliğine } \\
\text { neden olması .... (E-5, D-44) }\end{array}$ & 0 \\
\hline \multirow{3}{*}{  } & $\begin{array}{c}\text { Mevcut } \\
\text { (Net / Güçlü) }\end{array}$ & $\begin{array}{l}\text { Gerekçe güçlü ve net olarak desteklenir. } \\
\text { Ör: ... güneş enerji panelleri uzun vadede karlı ve kazançlı } \\
\text { bir iş. ... devlet garantisi verilmesi ve GES'ler için destek } \\
\text { verilmesi kazanç getirecektir. }(E-7, D-39)\end{array}$ & 2 \\
\hline & $\begin{array}{l}\text { Mevcut } \\
\text { (Zayif) }\end{array}$ & $\begin{array}{l}\text { Gerekçe net belli değildir, zayıf olarak desteklenir. } \\
\text { Ör: ... Özelliğini yitiren paneller \%20 oranında üretim } \\
\text { yapabilir. ... Eskiyen özelliğini yitiren panellerin bakımı } \\
\text { zor olacaktır. (E-7, D-38) }\end{array}$ & 1 \\
\hline & Yok & $\begin{array}{l}\text { Gerekçeyi desteklenecek öge bulunmaz. } \\
\text { Ör: ... Verimli arazilere yapılan ekim o bölge halkına } \\
\text { uygun olanaklar sağlayacaktır. }(E-7, D-42)\end{array}$ & 0 \\
\hline \multirow[t]{2}{*}{ :己己 } & $\begin{array}{l}\text { Mevcut } \\
\text { (Net / Güçlü) }\end{array}$ & $\begin{array}{l}\text { Savunduğu iddiaya karşı gerekçelendirerek veya } \\
\text { destekleyerek çürütücü üretir. } \\
\text { Ör: ... hidrojen sentetik olarak üretildiği ve yeni bir } \\
\text { kaynak olduğu için başlangıçta sanayi kuruluşları için ek } \\
\text { maliyet getirebilecektir. Ancak bu yeni teknoloji yeni bir } \\
\text { sektör oluşturacak ve yeni istihdamla birlikte maliyetlerin } \\
\text { ileride azalmasını sağlayabilir. ... (E-9, D-27) }\end{array}$ & 2 \\
\hline & $\begin{array}{l}\text { Mevcut } \\
\text { (Zayif) }\end{array}$ & $\begin{array}{l}\text { Savunduğu iddiaya karşı sadece çürütücü kullanılır. } \\
\text { Orr: ... Şimdi değil ama ilerleyen zamanlarda maliyet } \\
\text { düşer. }(\text { E-9, D-18) }\end{array}$ & 1 \\
\hline
\end{tabular}




\section{Yok \\ Savunduğu iddiaya karşı çürütücü kullanılmaz. \\ Ör: ... ülkemiz zengin bir ülke değil, maliyeti çok yüksek, \\ bize daha pahallya patlar. (E-9, D-30)}

Sınıf Öğretmeni adaylarının argüman oluşturma ortalama puanlarının ilk etkinlikten son etkinliğe doğru değişimi tek yönlü tekrarlı ölçümler ANOVA (Repeated Measure ANOVA) ve Friedman testi kullanılarak analiz edilmiştir. Sınıf öğretmeni adaylarının süreç boyunca argüman oluşturma ortalama puanlar arasındaki varyanslara göre etki büyüklüğü hesaplanmıştır. Etki büyüklüğü, ortalamalar arasındaki farkın standardize edilmiş bir ölçümü olarak tanımlanır ve standardize fark olarak rapor edilir (Çapık, 2014). Etki büyüklüğü hesaplamasında Cohen tarafından ortaya atılmış hesaplama (Cohen's $f$ ) temel alınmıştır. Cohen's $f$ hesaplamasında önce eta-kare değeri hesaplanmış ve Cohen's $f$ formülü ile süreç boyu argüman oluşturma ortalama puanlar arası değişimin etki büyüklüğü ortaya konulmuştur. Cohen's $f$ için 0.10 ila 0,24 aralığ küçük, 0,25 ila 0,39 aralığı orta ve 0,40 'dan büyük olması geniş etki olarak yorumlanır (Özsoy \& Özsoy, 2013). Etkinlik sürecinde devamsızlık haklarını kullanan ve o haftaki etkinliğe katılamayan sınıf öğretmeni adaylarının argüman oluşturma puanları "kayıp veri (missing value)" olarak atanarak analiz edilmiştir.

Argümantasyon Değerlendirme Ölçeği ise Erduran, Simon ve Osborne (2004) tarafindan Toulmin'in Argümantasyon Modeli temel alınarak hazırlanmıştır. Öğretmen adaylarının oluşturdukları argümanlarda, argüman bileşenlerinin (iddia, veri, gerekçe, destekleyici ve çürütücü) varlığı ve bileşenlerin net/güçlü olmasına göre düzeyler "Düzey 1-5" arasında belirlenmiştir. Bu ölçek araştırmacılar tarafından araştırmanın amacına göre uzman onayı alınarak ve yeniden düzenlenerek kullanılmıştır. Sınıf öğretmeni adaylarının bireysel ve grup olarak oluşturdukları argüman düzeyleri; Düzey 1 ve Düzey 2 düşük, Düzey 3 orta, Düzey 4 ve Düzey 5 ise yüksek argüman oluşturma düzeyi olarak belirlenmiştir. Bu sayede sınıf öğretmeni adaylarının argüman oluşturma düzeylerinin süreç içerisindeki değişimi daha rahat gözlemlenebilmiştir. Revize edilen ölçeğin son hali bu çalışmadaki öğretmen adaylarının ifadelerinden örneklerle birlikte Tablo 3’te sunulmuştur.

\section{Tablo 3. Argümantasyon Değerlendirme Ölçeği}

\begin{tabular}{|c|c|c|}
\hline $\begin{array}{l}\text { Argüman } \\
\text { Oluşturma } \\
\text { Düzeyi }\end{array}$ & & Argümantasyon İçeriği (Kriter) \\
\hline ঔે & & $\begin{array}{l}\text { Basit bir iddia veya iddia niteliği taşımayan gerekçeli bir cümle yer alır. } \\
\text { Ör: Ülke ekonomisinin zarar göreceği yönünde argüman öne sürülür. (Paris iklim } \\
\text { değişikliği antlaşmasının imzalanmaması iddiası anlaşılmaktadır. Diğer argüman } \\
\text { elemanları bulunmamaktadır.) }(E-4, D-15)\end{array}$ \\
\hline 总 & & $\begin{array}{l}\text { Basit bir iddia ile birlikte başka iddialar, gerekçe veya destekleyiciler herhangi } \\
\text { birisi olabilir ancak çürütücü içermez. } \\
\text { Ör: Güneş panellerinin ışınları elektrik enerjisine daha ucuz dönüştürmesinden } \\
\text { (gerekçe) dolayı desteklerim (iddia). }(E-7, D-22)\end{array}$ \\
\hline
\end{tabular}


$\mathrm{Bu}$ düzeyde diğer düzeylerde bulunan tüm bileşenlerin yanı sıra birden fazla net/güçlü çürütücü bulunmalıdır.

Ör: Rüzgâr panellerinin kurulmasını destekliyoruz (iddia). Öncelikli olarak RES'lerin kullanılacağ alanda önemli arazi çalışmaları yapılmalıdır. Bu alanların tarım arazisi, ormanlık alan, kuşların göç yolları ve yerleşkelere yakın olmaması gereklidir (güçlü çürütücüler). Bu şartlar sağlandiğında RES'ler hem yenilenebilir enerji kaynă̆ hem de çevreci olarak karşımıza çıkar (gerekçe 1). Kurulum maliyetini ucuz enerji üreterek karşllayabilir (gerekçe 2). Herhangi bir gaz salınımı yapmaz ve atık da ortaya çıkarmaz (gerekçe 1 destekleyici). Iklim değişikliğine veya asit yă̆murlarını sebep olmayacaktır (gerekçe 1 destekleyici). Petrol, doğalgaz gibi dışa bağımlılı̆̆ da azaltır (gerekçe 2 destekleyici). ÇED raporu hazırlanarak kurulması sağlanmalıdır (güçlü çürütücü). (E-6, G-2)

Sınıf öğretmeni adaylarının argümantasyon temelli öğretim süreci boyunca verilen senaryolara bireysel ve grup olarak savundukları destekleyici argümanların ve bu destekleyici argümanlara tam zıt oluşturdukları karşıt argümanların ortalama puanları ve düzeyleri, tablolar ve grafikler yardımıyla sunulmuştur.

\section{Geçerlik ve Güvenirlik}

Çalışmanın yapıldığı ortamda bulunmak araştırmacının önyargılarını kontrol etmesine yardımcı olabilmekte; veri toplamak için yeterli zamanın ayrılması ile araştırmacı örneklem grubunun kültürünü, dilini ya da görüşlerini anlamasını sağlar (Başkale, 2016). Bu nedenle uygulamalar on hafta devam etmiş ve argümantasyon temelli öğretim sürecine alışmaları ve süreci kavramaları sağlanmıştır. Araştırmacı, araştırmanın tüm aşamalarında mümkün olabildiğince objektif olmaya dikkat etmiştir.

Argümantasyon temelli öğretim süreci boyunca kullanılan çevre-enerji konularına yönelik senaryolar için üç uzmandan görüş alınmış ve gerekli düzeltmeler yapıldıktan sonra çalışma grubu dışındaki sınıf öğretmeni adaylarına uygulanarak pilot çalışması yapılmıştır. Böylece senaryoların argüman oluşturma becerilerini geliştirici nitelikte oldukları tespit 
edilmiştir. Araştırma niteliğini arttırmak ve araştırmalarda katılımcılarla yapılan görüşmelerin karmaşık olan kısımlarını daha rahat analiz etmek için formlar kullanılabilir (Roberts vd., 2006). Argümantasyon temelli öğretim süreci boyunca sınıf öğretmeni adaylarının oluşturdukları puan ortalamalarının hesaplamasında puanlama anahtarı ve değerlendirme ölçeği kullanılmıştır.

Nitel verilerin veya raporların gözden geçirilmesi ve değerlendirilmesi için çalışma dışından bireyler eklenebilir (Fraenkel, Wallen \& Hyun, 2012). Bu amaçla araştırmacı senaryolarda oluşturulan argümanların analizlerinin kodlanmasında, çalışma dışından bir kodlayıcıyı araştırmaya dahil etmiştir. Araştırmacının analiz ettiği nitel verileri kodlayıcı da analiz etmiş ve Huberman (2004) testi ile \%96'lık bir uyum tespit edilmiştir. Ayrıca veri analizlerinin güvenirliğini sağlamak amacıyla araştırmacı senaryoları iki ayrı zamanda kodlamış ve bu iki ayrı zaman sonunda \%92'lik bir uyum tespit edilmiştir. Bu iki yöntemle de veri analizlerinin güvenirliği sağlanmıştır.

Süreç boyunca oluşturulan elde edilen bulgular tablolarla ve açıklayıcı şekillerle okuyucuya sunulmaya çalışılmıştır. Araştırmanın tutarlılığını arttırmak için elde edilen bulguların doğrudan okuyucuya sunulmuş ve bulgular yorumlanarak, diğer bulgularla bağlantıları ortaya konulmaya çalışılmıştır. Araştırmanın teyit edilebilirliğini sağlamak için, verilerin nasıl toplandığ okuyucuya anlatılmıştır.

\section{Bulgular}

Argümantasyon temelli öğretim sürecinin uygulandığı sınıf öğretmeni adaylarının hazırlanan senaryolara vermiş oldukları cevaplar, "Argüman Yapısı Puanlama Anahtarına" göre değerlendirilmiş ve argüman oluşturma ortalama puanları elde edilmiştir. Sınıf öğretmeni adayları puanlama anahtarına göre en az 1, en fazla 9 puan almaktadırlar. Çevre-enerji konuları bağlamında sınıf öğretmeni adaylarının argüman oluşturma ortalama puanları dikkate alınarak oluşturulan alt problemlere ilişkin bulgular aşağıda sırasıyla sunulmuştur:

1.Argümantasyon Temelli Öğretim Sürecinin Uygulandığı On Farklı Etkinlik Sonunda Sınıf Öğretmeni Adaylarının Argüman Oluşturma Ortalama Puanları Arasında Anlamı Fark Var Mıdır?

\subsection{Sınıf öğretmeni adaylarının bireysel argüman oluşturma ortalama puanları arasında anlamlı bir fark var mıdır?}

Argümantasyon temelli öğretim süreci boyunca sınıf öğretmeni adaylarının bireysel argüman oluşturma ortalama puanları hesaplanmış ve ortalama puanlarındaki değişim Şekil 1'de sunulmuştur. 
Öğretmeni Adaylarının Argüman Oluşturabilmelerine Etkisi

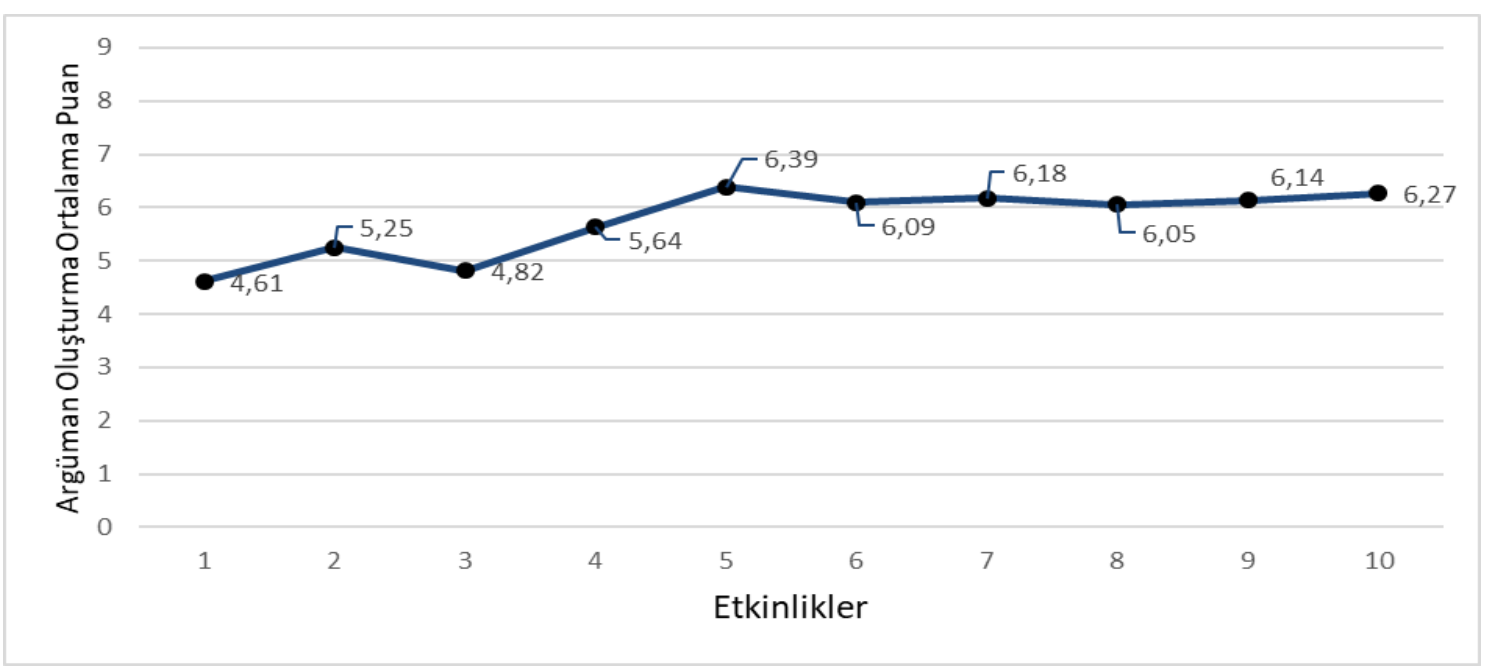

\section{Şekil 1. Bireysel argüman oluşturma ortalama puanlar arası değişim}

Şekil 1 incelendiğinde, sınıf öğretmeni adaylarının argümantasyon temelli öğretim süreci ilk haftasında bireysel argüman oluşturma ortalama puanları 4,61 iken, süreç boyunca bireysel argüman oluşturma ortalama puanlarında bir artış olduğu ve son hafta bu puanın 6,27'e yükseldiği görülmektedir. Sınıf öğretmeni adaylarının argümantasyon temelli öğretim süreci boyunca bireysel argüman oluşturma ortalama puanları arasındaki fark tek yönlü tekrarlı ölçümler ANOVA ile hesaplanmıştır. Tekrarlı ölçümler ANOVA'nın varsayımları test edilerek dağılımı normalliği ve küresellik (spericity) testi yapılmıştır. Etkinlik bazında bireysel argüman oluşturma ortalama puanları normallik testi sonucunda $\mathrm{p}>0,05$ bulunmuş, çarpıklık-basıklık katsayıları -2 ila +2 arasında olduğu tespit edilmiş ve küresellik testi sonucunda Mauchy's Test of Spericity değeri $\mathrm{p}>0,05$ olarak tespit edilerek tekrarlı ölçümler ANOVA varsayımları sağlanmıştır. Süreç boyunca, bireysel argüman oluşturma ortalama puanlar arası fark tek yönlü tekrarlı ölçümler ANOVA sonuçları ile Tablo 4’te sunulmuştur.

Tablo 4. Bireysel Argüman Oluşturma Ortalama Puanlar Arası Tekrarlı Ölçümler ANOVA Sonuçları

\begin{tabular}{|c|c|c|c|c|c|c|c|c|}
\hline Etkinlik & $\overline{\mathbf{x}}$ & $\begin{array}{c}\text { St. } \\
\text { Sapma }\end{array}$ & $\begin{array}{l}\text { Varsayın } \\
\text { Kaynağı }\end{array}$ & $\begin{array}{l}\text { Kareler } \\
\text { toplamı }\end{array}$ & sd & $\begin{array}{c}\text { Kareler } \\
\text { Ortalaması }\end{array}$ & $\mathbf{F}$ & $\mathbf{p}$ \\
\hline Etkinlik 1 & 4,61 & 1,47 & Denekler arası & 14513,020 & 1 & 14513,020 & \multirow{4}{*}{16,319} & \multirow{4}{*}{0,000} \\
\hline Etkinlik 2 & 5,25 & 1,36 & Hata & 113,880 & 43 & 2,648 & & \\
\hline Etkinlik 3 & 4,82 & 1,10 & Ölçüm & 160,139 & 9 & 17,793 & & \\
\hline Etkinlik 4 & 5,64 & 1,41 & Toplam & 14787,039 & 53 & 14533,461 & & \\
\hline Etkinlik 5 & 6,39 & 1,25 & & & & & & \\
\hline Etkinlik 6 & 6,09 & 1,36 & & & & & & \\
\hline Etkinlik 7 & 6,18 & 1,43 & & & & & & \\
\hline Etkinlik 8 & 6,05 & 0,98 & & & & & & \\
\hline Etkinlik 9 & 6,14 & 0,96 & & & & & & \\
\hline Etkinlik 10 & 6,27 & 1,46 & & & & & & \\
\hline
\end{tabular}


Tablo 4'teki veriler incelendiğinde sınıf öğretmeni adaylarının bireysel argüman oluşturma ortalama puanlarında ilk etkinlikten son etkinliğe doğru bir artışın olduğu ve ortalama puanlar arası farkın da istatiksel olarak anlamlı olduğu $(\mathrm{p}<0,05)$ tespit edilmiştir. Bireysel argüman oluşturma ortalama puanlar arası farkın etki büyüklüğü Cohen's $f: 0,62$ olarak hesaplanmış ve bu değer $0,40<$ Cohen's $f$ olduğundan geniş etki olarak yorumlanmıştır. Çevreenerji konuları bağlamında, argümantasyon temelli öğretim süreci boyunca sınıf öğretmeni adaylarının bireysel argüman oluşturma ortalama puanlar anlamlı şekilde artmıştır. Dolayısıyla sınıf öğretmeni adayları argümantasyon temelli öğretim süreci boyunca bireysel argüman puanlarını arttırarak daha nitelikli argümanlar üretebilmeyi başarmışlardır.

\subsection{Sınıf öğretmeni adaylarının grup argümanı oluşturma ortalama puanları arasında anlamlı bir fark var mıdır?}

Argümantasyon temelli öğretim süreci boyunca sınıf öğretmeni adaylarının savundukları grup argümanı oluşturma ortalama puanları hesaplanmış ve ortalama puanlarındaki değişim Şekil 2'de sunulmuştur.



\section{Şekil 2. Grup argümanı oluşturma ortalama puanlar arası değişimi}

Şekil 2 incelendiğinde, sınıf öğretmeni adaylarının argümantasyon temelli öğretim sürecinin ilk haftasında grup argümanı oluşturma ortalama puanları 5,13 iken, süreç boyunca adayların grup argümanı oluşturma ortalama puanlarında artış görülmüş ve uygulamanın son haftasında bu puan 7,25'e yükselmiştir. Sınıf öğretmeni adaylarının argümantasyon temelli öğretim süreci boyunca grup argüman oluşturma ortalama puanları arasındaki fark, tekrarlı ölçümler ANOVA varsayımlarını sağlamadığı için bu testin nonparametrik karşılığı olan Friedman testi ile analiz edilmiştir. Süreç boyunca, grup argümanı oluşturma ortalama puanları arası farka yönelik Freidman test sonuçları Tablo 5 'te sunulmuştur. 
Öğretmeni Adaylarının Argüman Oluşturabilmelerine Etkisi

Tablo 51. Grup Argümanı Oluşturma Ortalama Puanlar Arası Freidman Testi Sonuçları

\begin{tabular}{|c|c|c|c|c|}
\hline Etkinlik & Sira Ortalaması & $\begin{array}{c}\text { Chi-Square } \\
\mathbf{x}^{2} \\
\end{array}$ & sd & $\mathbf{p}$ \\
\hline Etkinlik 1 & 3,06 & & & \\
\hline Etkinlik 2 & 4,88 & 24,492 & 9 & 0,004 \\
\hline Etkinlik 3 & 3,88 & & & \\
\hline Etkinlik 4 & 3,88 & & & \\
\hline Etkinlik 5 & 7,69 & & & \\
\hline Etkinlik 6 & 5,63 & & & \\
\hline Etkinlik 7 & 6,06 & & & \\
\hline Etkinlik 8 & 4,94 & & & \\
\hline Etkinlik 9 & 7,25 & & & \\
\hline Etkinlik 10 & 7,75 & & & \\
\hline
\end{tabular}

$\mathrm{x}^{2}(9, \mathrm{n}=8)=24,492 ; \mathrm{p}=0,004$

Tablo 5'deki veriler incelendiğinde sınıf öğretmeni adaylarının grup argümanı oluşturma ortalama puanlarının sıra ortalamalarında bazı haftalarda düzensizlik (iniş-çıkış) yaşanmıştır. Bazı haftalardaki düzensizliğin (2., 6., 7. ve 8. etkinlik) nedenleri, sınıf öğretmeni adaylarının ilk haftalarda argümantasyon sürecine tam alışamamaları (2. Etkinlik) ve sürecin sonlarına doğru motivasyonlarının kaybolmasından kaynaklı olabilir. Ancak sınıf öğretmeni adaylarının grup argümanı oluşturma ortalama puanlarının sıra ortalamalarında ilk etkinlikten son etkinliğe doğru bir artışın olduğu ve ortalama puanlar arası farkın istatiksel olarak anlamlı olduğu görülmüştür $(\mathrm{p}<0,05)$. Çevre-enerji konuları bağlamında, argümantasyon temelli ögretim süreci boyunca sınıf ögrretmeni adaylarının grup argüman oluşturma ortalama puanları anlamlı şekilde artmıştır. Bu sonuç uygulanan grup etkinliklerinin sınıf öğretmeni adaylarının grup argümanı oluşturma ortalamalarını arttırarak daha nitelikli grup argümanı oluşturdukları şeklinde yorumlanabilir.

\subsection{Sınıf öğretmeni adaylarının bireysel karşıt argüman oluşturma ortalama puanları arasında anlamlı bir fark var mıdır?}

Argümantasyon temelli öğretim süreci boyunca sınıf öğretmeni adaylarının bireysel karşıt argüman oluşturma ortalama puanları hesaplanmış ve Şekil 3'de sunulmuştur.



Şekil 3. Bireysel karşıt argüman oluşturma ortalama puanlar arası değişim 
Şekil 3 incelendiğinde, sınıf öğretmeni adaylarının argümantasyon temelli öğretim sürecinin ilk haftasında bireysel karşıt argüman oluşturma ortalama puanları 2,95 iken, sürecin son haftasında bu puan 5,09 puana yükselmiştir. Ayrıca yukarıdaki grafik incelendiğinde sürecin ilk üç haftasında ortalama puanlarda çok fark gözlemlenmezken, dördüncü haftadan son haftaya doğru karşıt argüman oluşturma ortalama puanlarında artış olduğu gözlemlenmiştir. 5 numaralı etkinlikte bireysel karşıt argüman oluşturma ortalama puanlarının yüksek olması, "nükleer enerji santralı" senaryosunun bu dönemde kamuoyunda güncel olarak tartışılmakta olmasıyla ve karşıt argüman oluşturmaya müsait bir yapıda olmasıyla açıklanabilir. Aynı zamanda 6 numaralı etkinlikte "Rüzgar Enerji Santrallerini" destekleyici bireysel argümanların çoğunlukta olması ve sınıf öğretmeni adaylarının bu senaryoda karşıt argüman oluşturmakta zorlanmalarıyla açıklanabilir.

Sınıf öğretmeni adaylarının argümantasyon temelli öğretim süreci boyunca bireysel karşıt argüman oluşturma ortalama puanları arasındaki fark tek yönlü tekrarlı ölçümler ANOVA ile hesaplanmıştır. Tekrarlı ölçümler ANOVA'nın varsayımları test edilerek dağılımı normalliği ve küresellik (spericity) testi yapılmıştır. Etkinlik bazında bireysel karşıt argüman oluşturma ortalama puanları normallik testi sonucunda $\mathrm{p}>0,05$ bulunmuş, çarpıklık-basıklık katsayıları -2 ila +2 arasında olduğu tespit edilmiş ve küresellik testi sonucunda Mauchy's Test of Spericity değeri p $>0,05$ olarak tespit edilerek tekrarlı ölçümler ANOVA varsayımları sağlanmıştır. Süreç boyunca, bireysel karşıt argüman oluşturma ortalama puanlar arası fark tekrarlı ölçümler ANOVA sonuçları ile Tablo 6'da sunulmuştur.

Tablo 6. Bireysel Karşıt Argüman Oluşturma Ortalama Puanlar Arası Tekrarlı ANOVA Sonuçları

\begin{tabular}{|c|c|c|c|c|c|c|c|c|}
\hline Etkinlik & $\overline{\mathbf{X}}$ & $\begin{array}{c}\text { St. } \\
\text { Sapma }\end{array}$ & $\begin{array}{l}\text { Varsayın } \\
\text { Kaynağı }\end{array}$ & $\begin{array}{l}\text { Kareler } \\
\text { toplamı }\end{array}$ & sd & $\begin{array}{c}\text { Kareler } \\
\text { Ortalaması }\end{array}$ & $\mathbf{F}$ & $\mathbf{p}$ \\
\hline Etkinlik 1 & 2,95 & 1,47 & $\begin{array}{c}\text { Denekler } \\
\text { arası }\end{array}$ & 7209,002 & 1 & 7209,002 & \multirow{4}{*}{21,931} & \multirow{4}{*}{0,000} \\
\hline Etkinlik 2 & 2,91 & 1,36 & Hata & 122,498 & 43 & 2,849 & & \\
\hline Etkinlik 3 & 3,00 & 1,10 & Ölçüm & 305,839 & 9 & 33,982 & & \\
\hline Etkinlik 4 & 3,82 & 1,41 & Toplam & 7637,339 & 53 & 7245,833 & & \\
\hline Etkinlik 5 & 4,64 & 1,24 & & & & & & \\
\hline Etkinlik 6 & 3,89 & 1,36 & & & & & & \\
\hline Etkinlik 7 & 4,18 & 1,43 & & & & & & \\
\hline Etkinlik 8 & 5,09 & 0,98 & & & & & & \\
\hline Etkinlik 9 & 4,91 & 0,95 & & & & & & \\
\hline Etkinlik 10 & 5,09 & 1,46 & & & & & & \\
\hline
\end{tabular}

Tablo 6'daki veriler incelendiğinde, sınıf öğretmeni adaylarının bireysel karşıt argüman oluşturma ortalama puanlarında, ilk etkinlikten son etkinliğe doğru bir artışın olduğu ve bu artışın da istatiksel olarak anlamlı olduğu görülmektedir $(\mathrm{p}<0,05)$. Bireysel karşıt argüman oluşturma ortalama puanları arası farkın etki büyüklüğü Cohen's $f: 0,71$ olarak hesaplanmış ve 
Öğretmeni Adaylarının Argüman Oluşturabilmelerine Etkisi

bu değer $0,40<$ Cohen's $f$ olduğundan geniş etki olarak yorumlanmıştır. Dolayıslyla, argümantasyon temelli ögretim süreci boyunca sınıf ögretmeni adaylarının bireysel karşıt argüman oluşturma ortalama puanları anlamlı şekilde artmıştır. Bu sonuç yapılan uygulamanın sınıf ögretmeni adaylarının bireysel karşıt argüman oluşturma becerisini geliştirme noktasında yararlı olmuştur şeklinde yorumlanabilir.

\subsection{Sınıf öğretmeni adaylarının grup karşıt argümanı oluşturma ortalama puanları arasında anlamlı bir fark var midır?}

Argümantasyon temelli öğretim süreci boyunca sınıf öğretmeni adaylarının grup karşıt argümanı oluşturma ortalama puanları hesaplanmış ve ortalama puanlarındaki değişim Şekil 4'te sunulmuştur.

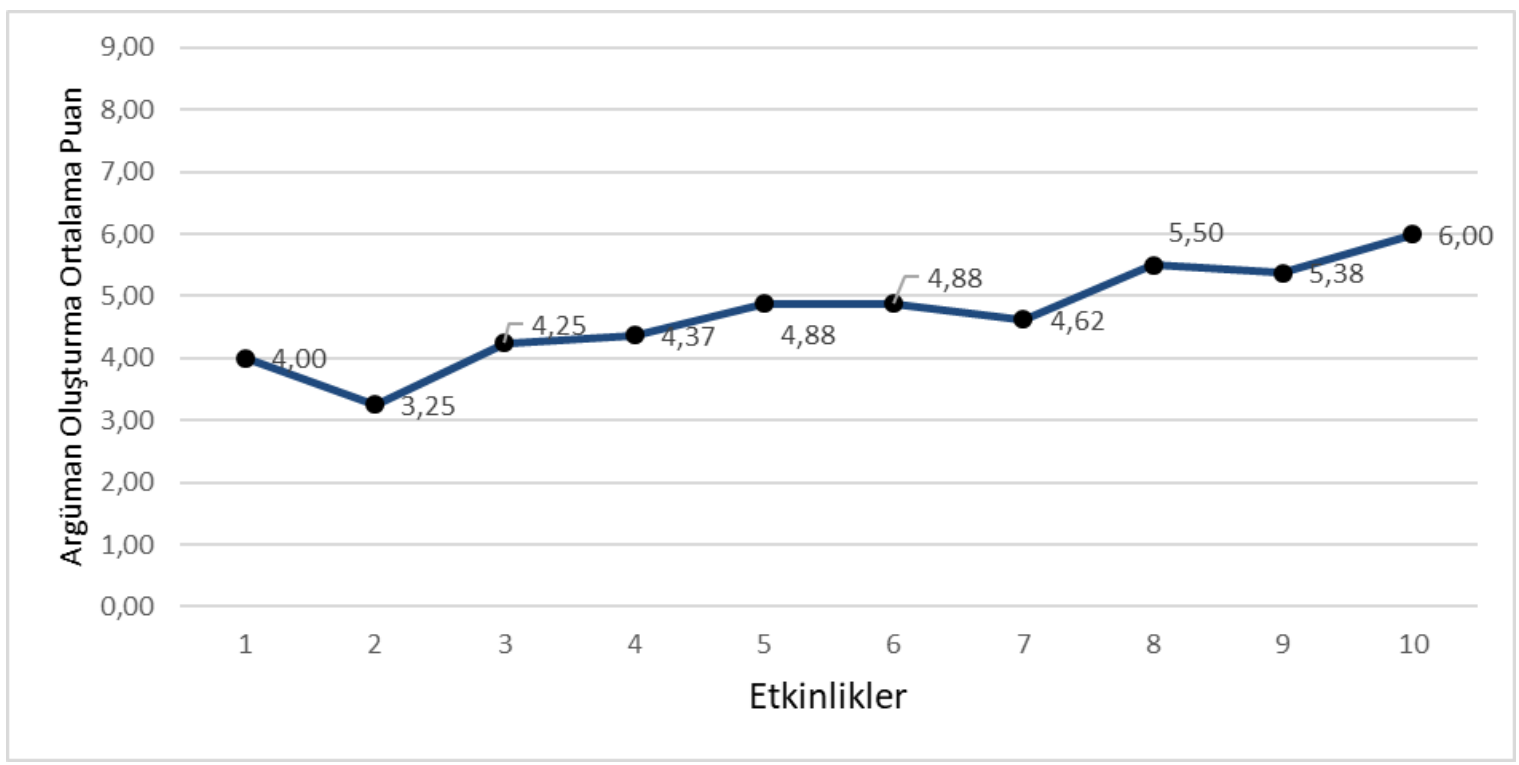

\section{Şekil 4. Grup karşıt argüman oluşturma ortalama puanlar arası değişim}

Şekil 4 incelendiğinde, sınıf öğretmeni adaylarının argümantasyon temelli öğretim sürecinin ilk haftasında grup karşıt argümanı oluşturma ortalama puanları 4,00 iken son haftasında bu puan 6,00 puana yükselmiştir. Ayrıca yukarıdaki grafik incelendiğinde sürecin ilk iki haftasında ortalama puanlarda azalma gözlemlenirken, üç ve dördüncü haftadan son haftaya doğru karşıt argüman oluşturma ortalama puanlarında artış olduğu görülmüştür. Sınıf öğretmeni adaylarının argümantasyon temelli öğretim süreci boyunca grup karşıt argüman oluşturma ortalama puanları arasındaki fark, tekrarlı ölçümler ANOVA varsayımlarını sağlamadığı için, bu testin nonparametrik karşıllğı olan Friedman testi ile analiz edilmiştir. Süreç boyunca, grup karşıt argümanı oluşturma ortalama puanları arası farka yönelik Freidman test sonuçları Tablo 7'de sunulmuştur. 
Tablo 7. Grup Karşıt Argüman Oluşturma Ortalama Puanlar Arası Freidman Testi Sonuçları

\begin{tabular}{|c|c|c|c|c|}
\hline Etkinlik & Sira Ortalaması & $\begin{array}{c}\text { Chi-Square } \\
\mathbf{x}^{2}\end{array}$ & df & $\mathbf{p}$ \\
\hline Etkinlik 1 & 3,81 & & & \\
\hline Etkinlik 2 & 3,13 & 19,195 & 9 & 0,024 \\
\hline Etkinlik 3 & 4,38 & & & \\
\hline Etkinlik 4 & 4,94 & & & \\
\hline Etkinlik 5 & 6,25 & & & \\
\hline Etkinlik 6 & 5,94 & & & \\
\hline Etkinlik 7 & 5,19 & & & \\
\hline Etkinlik 8 & 7,38 & & & \\
\hline Etkinlik 9 & 7,06 & & & \\
\hline Etkinlik 10 & 6,94 & & & \\
\hline
\end{tabular}

Tablo 7'deki veriler incelendiğinde, sınıf öğretmeni adaylarının grup karşıt argüman oluşturma ortalama puanlarının sıra ortalamalarında, ilk etkinlikten son etkinliğe doğru bir artışın olduğu ve ortalama puanlar arası farkın da istatiksel olarak anlamlı olduğu görülmüştür $(\mathrm{p}<0,05)$. Çevre-enerji konuları bağlamında, argümantasyon temelli ögretim süreci boyunca sınıf ögrretmeni adaylarının grup karşıt argüman oluşturma ortalama puanları anlamlı şekilde artmıştır. Bu sonuç uygulanan grup etkinliklerinin sınıf öğretmeni adaylarının grup karşıt argüman oluşturma ortalamalarını arttırarak daha nitelikli grup argümanı oluşturdukları şeklinde yorumlanabilir.

\section{Argümantasyon Temelli Öğretim Sürecinin Uygulandığı On Farklı Etkinlik Sonunda Sınıf Öğretmeni Adaylarının Argüman Oluşturma Düzeyleri Nasıl Değişmiştir?}

$\mathrm{Bu}$ çalışmada argümantasyon temelli öğretim sürecinin uygulandığı sınıf öğretmeni adaylarının hazırlanan senaryolara vermiş oldukları cevaplar, "Argümantasyon Değerlendirme Ölçeği’ne" göre değerlendirilmiş ve argüman oluşturma düzeyleri belirlenmiştir. Sınıf öğretmeni adayları oluşturdukları argümanların içeriğine göre en az Düzey 1, en fazla Düzey 5'te yer almaktadır. Sınıf öğretmeni adaylarının bireysel ve grup olarak oluşturdukları savundukları ve karşıt argüman düzeyleri Düzey 1 ve Düzey 2 düşük; Düzey 3 orta; Düzey 4 ve Düzey 5 ise yüksek argüman oluşturma düzeyi olarak belirlenmiştir. Düzey belirlemedeki amaç, süreç içerisinde sınıf öğretmeni adaylarının argüman oluşturma düzeylerindeki değişimi daha rahat gözlemleyebilmektir. Çevre-enerji konuları bağlamında sınıf öğretmeni adaylarının argüman oluşturma düzeyleri esas alınarak oluşturulan alt problemlere ilişkin bulgular sırasıyla sunulmuştur:

\subsection{Sını öğretmeni adaylarının bireysel argüman oluşturma düzeyleri nasıl değişmişstir?}

Sınıf öğretmeni adaylarının argümantasyon temelli öğretim süreci boyunca oluşturdukları bireysel argümanların düzeyleri belirlenmiş ve düzeylerin değişimi Şekil 5'de sunulmuştur. 


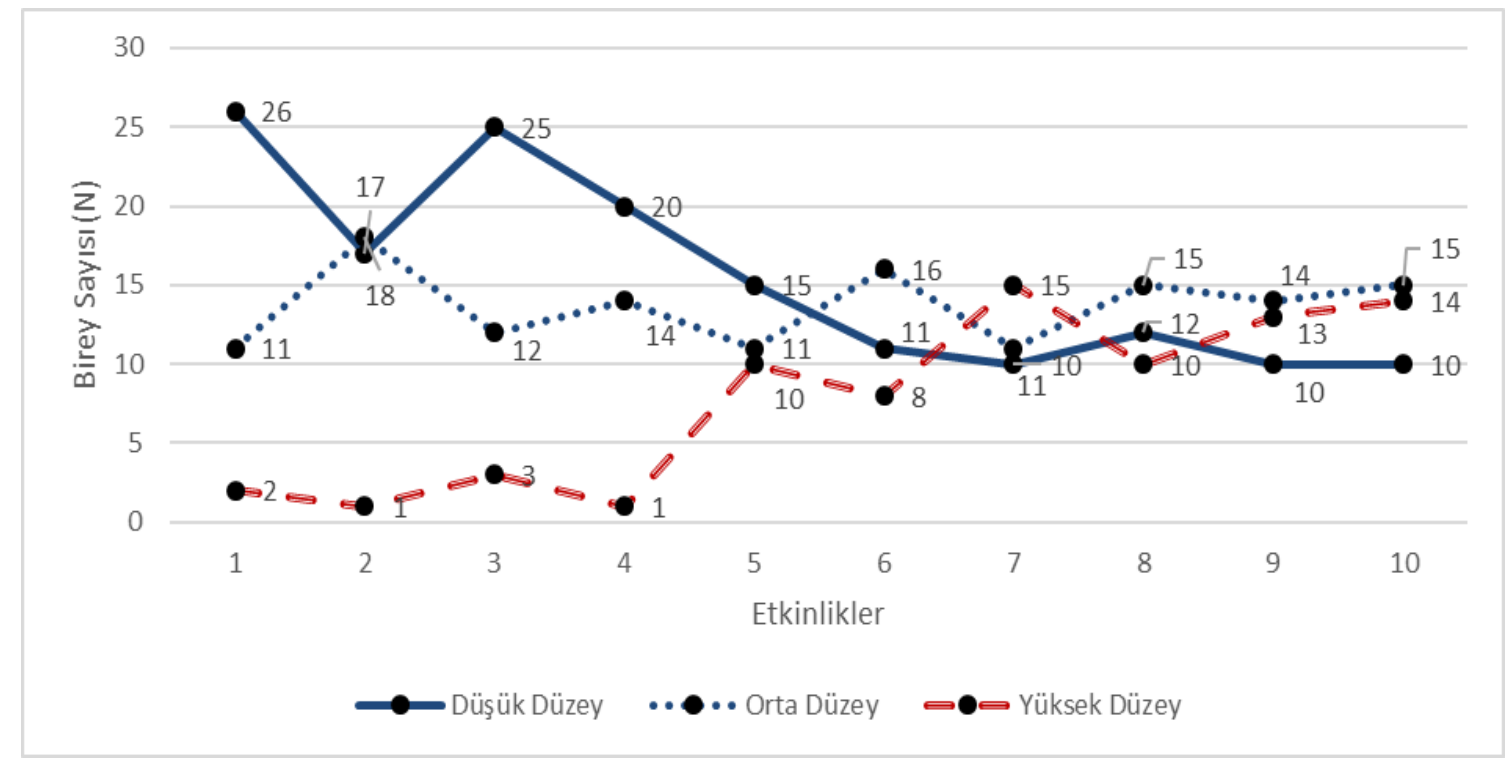

\section{Şekil 5. Bireysel argüman oluşturma düzeylerinin süreç içerisindeki değişimi}

Şekil 5 incelendiğinde, argümantasyon temelli öğretim süreci boyunca düşük düzeyde bireysel argüman oluşturan sınıf öğretmeni adaylarının sayısı ilk etkinlikte 26 iken, süreç sonunda azalarak 10'a düşmüştür. Orta düzey argüman oluşturan aday sayısı ilk hafta 11 iken, süreç boyu artarak 15'e yükselmiş, aynı şekilde yüksek düzey argüman üreten aday sayısı ilk hafta 2 iken, süreç boyu artarak 14'e kadar yükselmiştir. Sınıf öğretmeni adaylarının süreç başında düşük düzeyde argüman oluşturmaları argümantasyon temelli öğretim süreci ile ilk kez karşı karşıya kalmalarıyla açıklanabilir. Özellikle 5. etkinlikle birlikte düzeyler birbirine yaklaşmış ve ileriki etkinliklerde orta ve yüksek düzey bireysel argüman oluşturan sınıf öğretmeni aday sayısı daha da artmıştır. Bu durum süreç boyunca daha kaliteli argüman oluşturabilmeleri ile açıklanabilir. Bu sonuç argümantasyon temelli öğretim sürecinin sınıf ögretmeni adaylarının daha yüksek düzeyli argüman oluşturmalarını sağlamakta etkili olduğu şeklinde yorumlanabilir.

\subsection{Sınıf öğretmeni adaylarının grup argüman oluşturma düzeyleri nassl değişmiştir?}

Sınıf öğretmeni adaylarının argümantasyon temelli öğretim süreci boyunca oluşturdukları grup argümanlarının düzeyleri belirlenmiş ve düzeylerin değişimi Şekil 6'da sunulmuştur. 


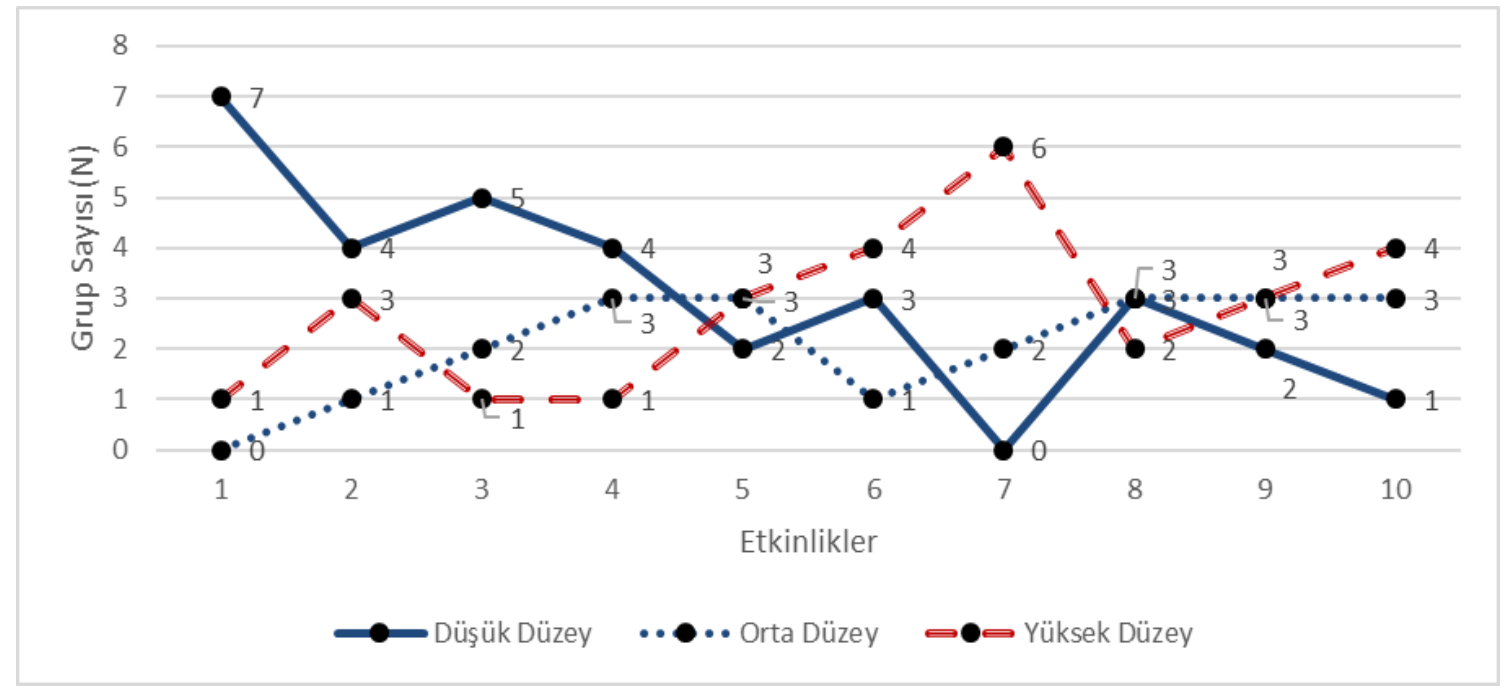

\section{Şekil 6. Grup argümanı oluşturma düzeylerinin süreç içerisindeki değişimi}

Şekil 6'da, argümantasyon temelli öğretim sürecinin ilk haftasında düşük düzeyde grup argümanı oluşturan grup sayısı 7 iken, süreç boyunca azalmış ve 1'e düşmüştür. İlk etkinlikte orta düzey grup argümanı oluşturan grup sayısı 1 iken süreç boyu artmış ve 4'e yükselmiştir. Aynı şekilde yüksek düzey grup argümanı oluşturan grup sayısı ilk hafta hiç yokken, süreç boyu artarak son hafta 3'e yükselmiştir. Bu sonuç ilk kez argümantasyon temelli öğretim süreci ile karşılaşan sınıf öğretmeni adaylarının düşük düzeyde argüman oluşturdukları ancak ilerleyen süreçte daha yüksek düzeyde argüman oluşturmayı başardıkları şeklinde yorumlanabilir. Bireysel argüman oluşturma düzeyinde olduğu gibi grup argümanı oluşturma düzeyinde de 5 . etkinlikle birlikte düzeyler birbirine yaklaşmıştır. Hatta ileriki etkinliklerde grupların orta ve yüksek düzey grup argümanı oluşturdukları görülmüştür. Rüzgar enerji santrallerinin senaryolaştırıldığ 6 . etkinlikte ve güneş enerji santrallerinin senaryolaştırdığ 1 7. etkinlikte sınıf öğretmeni adayları grupça daha yüksek düzeyde argüman oluştururmuşlardır. Bu enerji kaynaklarının çevre-enerji konuları bağlamında argüman olarak desteklenmeye daha müsait konular olması, bu durumun oluşmasında etkili olmuş olabilir. Ancak jeotermal enerji santralinin senaryolaştırıldığ 8 . etkinlikte düşük argüman oluşturan grupların sayısı artmış ve bu etkinlikte düzeyler tekrar yaklaşmıştır. Jeotermal kaynakların ülkemizde daha çok sağlık ve turizm amaçlı kullanılmasından ve enerji santrali kurulumu açısından daha kısıtlı örneklerinin olmasından dolayı gruplar argüman oluşturmakta zorlanmış olabilirler. Sonuç olarak sınıf ögretmeni adaylarının argümantasyon temelli ögretim süreci boyunca oluşturdukları grup argümanlarının düzey sayıları orta ve yüksek düzeye doğru ilerleme göstermiştir. Bu sonuç argümantasyon temelli öğretim süreci boyunca uygulanan grup etkinliği çalışmaları argüman oluşturma düzeylerini daha yüksek düzeylere çıartmada etkili olmuştur şeklinde yorumlanabilir.

\subsection{Sınıf öğretmeni adaylarının bireysel karşst argüman oluşturma düzeyleri nasıl değişmiştir?}

Sınıf öğretmeni adaylarının argümantasyon temelli öğretim süreci boyunca oluşturdukları bireysel karşıt argümanların düzeyleri belirlenmiş ve düzeylerin değişimi Şekil 7'de sunulmuştur. 
Öğretmeni Adaylarının Argüman Oluşturabilmelerine Etkisi

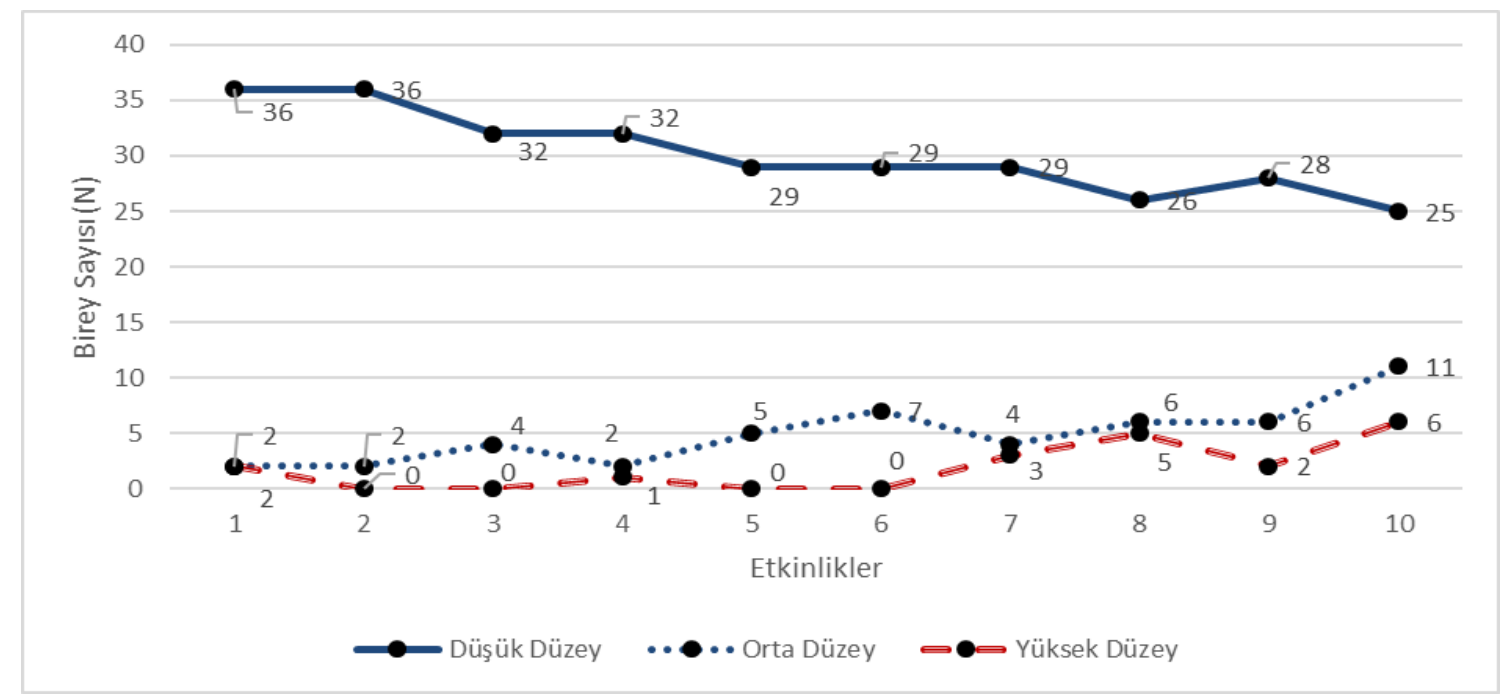

\section{Şekil 7. Bireysel karşıt argüman oluşturma düzeylerinin süreç içerisindeki değişimi}

Şekil 7 incelendiğinde, sınıf öğretmeni adaylarının argümantasyon temelli öğretim süreci başında düşük düzeyde bireysel karşıt argüman oluşturma sayıları 36 iken, son hafta bu say1 25'e düşmüştür. Orta ve yüksek düzeyde bireysel karşıt argüman oluşturma sayıları 2 iken, süreç sonunda orta düzeyde 11'e, yüksek düzeyde ise 6'ya yükselmiştir. Ancak bu artışın yeterli düzeyde olmadığı ve düşük düzeyde argüman oluşturan aday sayısının yüksek olduğu yukarıdaki grafikten daha rahat anlaşılmaktadır. Sonuç olarak, sınıf öğretmeni adaylarının argümantasyon temelli ögretim süreci boyunca oluşturduklarl bireysel karşıt argüman düzey sayıları orta ve yüksek düzeye doğru ilerleme göstermiş ancak yeterli miktarda olmadiğı sonucuna ulaşılabilir. Bu noktadan hareketle 10 haftalık uygulama sürecinin karşıt argüman oluşturma düzeylerini arttırma bakımından yeterli olmadığı ancak empatik bir anlayışla bu sürecin devam ettirilmesi halinde karşıt argüman oluşturma düzeyinin yeterli seviyeye gelebileceği söylenebilir.

\subsection{Sınıf öğretmeni adaylarının grup karşıt argüman oluşturma düzeyleri nasıl değişmişstir?}

Sınıf öğretmeni adaylarının argümantasyon temelli öğretim süreci boyunca oluşturdukları grup karşıt argümanlarının düzeyleri belirlenmiş ve düzeylerin değişimi Şekil 8'de sunulmuştur.

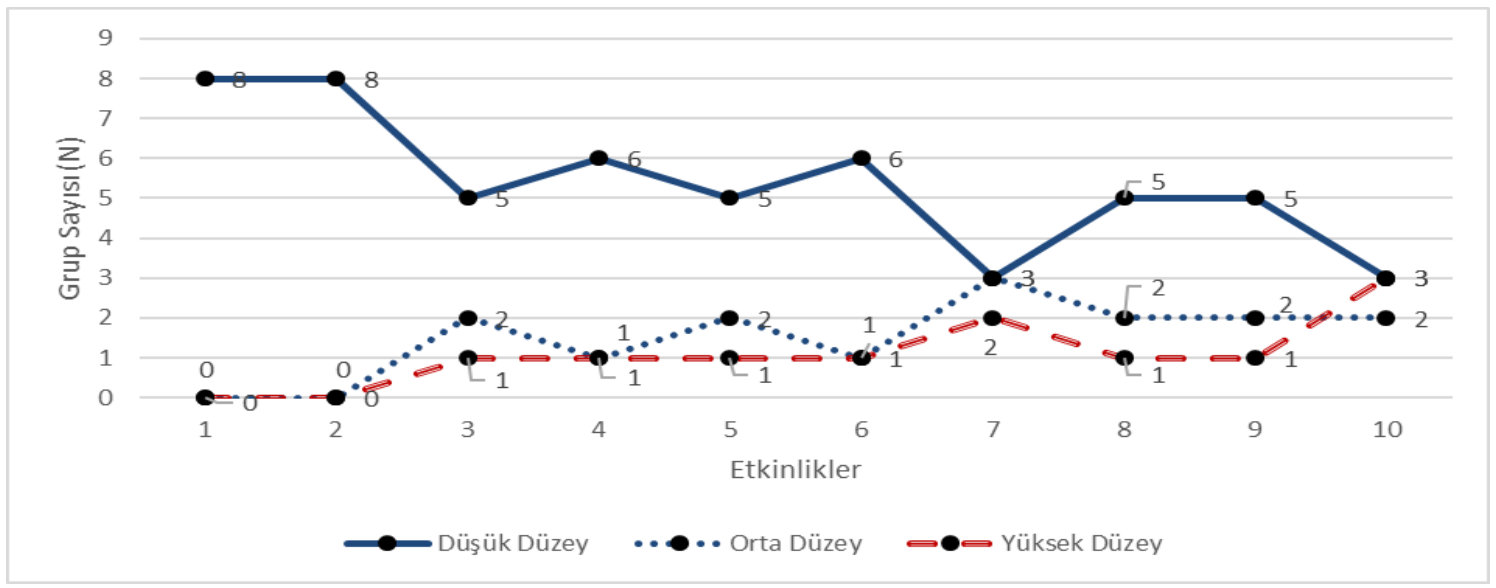

Şekil 8. Grup karşıt argüman oluşturma düzeylerinin süreç içerisindeki değişimi 
Şekil 8 incelendiğinde, argümantasyon temelli öğretim süreci başında düşük düzeyde grup karşıt argümanı oluşturan grup sayısı 8 iken, süreç sonunda 3'e düşmüştür. Süreç başında orta ve yüksek düzey argüman oluşturan grup sayısı bulunmazken, süreç sonunda orta düzey sayısı 2'e, yüksek düzey sayısı 3'e yükselmiştir. Yukarıdaki grafik incelendiğinde düşük düzey sayısındaki azalış ve orta ve yüksek düzey sayılarındaki artış görülebilir. Jeotermal enerji kaynağının senaryolaştırıldığ 1 . grup etkinliğinde grup argümanı oluşturma düzeylerinde ortaya çıkan durum, grup karşıt argüman oluşturma düzeylerinde de kendini göstermiştir. Sonuç olarak sını öğretmeni adaylarının argümantasyon temelli ögretim süreci boyunca oluşturduklarl grup karşıt argümanlarının düzeyleri orta ve yüksek düzeye doğru ilerleme göstermiştir. Bu durum süreç boyu uygulanan grup etkinliklerinin, adayların grup karşıt argümanı oluşturma düzeylerini bireysel karşıt argüman oluşturma düzeylerine göre daha çabuk yükselttiği şeklinde yorumlanabilir.

\section{Tartışma ve Sonuç}

Araştırma sonucunda, argümantasyon temelli öğretim süreci boyunca sinıf öğretmeni adaylarının bireysel, grup, bireysel karşıt ve grup karşıt argüman oluşturma ortalama puanlarında ilk etkinlikten son etkinliğe doğru bir artışın olduğu, ortalama puanlar arası farkın da istatiksel olarak anlamlı olduğu ve bireysel ve bireysel karşıt argüman ortalama puanlar arası farkın etki büyüklüğünün de "geniş etki" olduğu tespit edilmiştir. Ortalama puanlar, argüman yapısı puanlama anahtarına göre hesaplanmış ve puanlardaki artış, adayların argüman yapısında yer alan argüman bileşenlerini (iddia, veri, gerekçe, destekleyici ve çürütücü) kullanmalarına göre hesaplanmıştır. Bu puan artışı süreç içerisinde sınıf öğretmeni adaylarının daha fazla argüman bileşenlerini kullandıkları yani daha nitelikli argüman ürettikleri anlamına gelmektedir. Lazarou (2009) argümantasyon yönteminin kullanılmasının zaman içerisinde ilkokul öğrencilerinin daha kaliteli argüman oluşturmalarında olumlu gelişmeler yarattığını ortaya koymuştur. Aktaş (2017) araştırmasını ortaokul öğrencilerine yönelik "argümana dayalı sorgulama" modeli temel alarak tasarlamış ve araştırma süreci sonuna doğru deney grubu öğrencilerinin daha kaliteli argümanlar oluşturdukları sonucuna ulaşılmıştır. Hasançebi (2014) çalışmasında argümantasyon tabanlı öğrenme yaklaşımının ilköğretim öğrencilerinin yazılı argüman oluşturma becerilerinin gelişimine katkı sağladığını vurgulamış ve bu yaklaşım sonunda öğrencilerin özgüven, kendini ifade etme, iletişim kurma gibi bireysel özelliklerinde olumlu yönde gelişme olduğunu kaydetmiştir.

Araştırma sonucunda, sınıf öğretmeni adaylarının argüman düzeyleri süreç boyunca ilk haftadan son haftaya doğru orta ve yüksek düzeye doğru ilerleme göstermiştir. Dolayısıyla adaylar süreç ilerledikçe zayıf/güçlü çürütücü kullanmaya başlayarak argüman düzeylerini yükseltme eğilimi göstermişlerdir. Torun (2015) tarafından ortaokul yedinci sınıf öğrencileri ile yapılan bir araştırmada, argümantasyon temelli yürütülen sosyal bilgiler dersinin öğrencilerin argüman düzeylerini ve kalitesini arttırdığı tespit edilmiştir. Benzer şekilde beşinci sınıf öğrencilerinin argümantasyon sürecini zamanla daha iyi kavradıkları ve üst düzeyde argümanlar oluşturabildikleri (Çınar, 2013); argümantasyon süreci sonunda lise dokuzuncu sınıf öğrencilerinin argümantasyon kalitelerinde süreç başına göre artış olduğu (Çetin, Kutluca \& Kaya, 2013) bilimsel çalışmalarla ortaya konulmuştur. Demirel (2017) argüman sürecini üç boyutlu arttırılmış gerçeklik uygulamaları ile zenginleştirmiş ve ortaokul öğrencilerinin daha üst düzey argüman oluşturmayı başarabildiklerini görmüştür. Bu çalışmada öğrenci argümanlarının 
çoğunun 4 ve 5 . düzeyde olduğu ayrıca öğrencilerin bilimsel konulara göre sosyobilimsel konularda daha kaliteli argümanlar ürettikleri görülmüştür. Bu araştırmada sınıf öğretmeni adaylarının argüman oluşturma düzeylerinin daha üst düzeye çıkartılması için sosyobilimsel konulara yönelik senaryolar kullanılmış ve grup tartışmaları yapılmıştır. Çalışma sonunda sınıf öğretmeni adaylarının 10 haftada argüman düzeyleri artmış ve daha kaliteli argüman oluşturabildikleri görülmüştür.

$\mathrm{Bu}$ çalışmada sınıf öğretmeni adaylarının oluşturdukları bireysel karşıt argümanlardaki süreç boyunca ilerleyişin diğerlerine göre yeterli seviyede olmadığı sonucuna ulaşılmıştır. Bu durum karşıt argüman ortalama puanlarının bireysel savundukları argüman ortalama puanlarından daha düşük olması ile de bağlantılıdır. Yani adaylar karşıt argüman oluşturmada, hem ortalama puanda hem de düzeyde düşük seviyededir. Öğretmen adayları kendi argümanlarını savunurken, grup arkadaşlarını ikna etme güdüsüyle daha çok argüman boyutunu kullanmıştır. Karşıt argüman üretmede ikna etme zorunluluğunun bulunmaması öğretmen adaylarının bu konuda yetersiz kalmalarının sebebi olabilir. Başka bir sebep ise sınıf öğretmeni adaylarının sosyo-bilimsel durumlara, başkasının gözünden bakmakta yani empatik bir bakış açısı ile bu durumları değerlendirmekte zorlanmış olmalarıdır. Acar (2009) çalışmasında fen bilgisi öğretmen adaylarının argümantasyon becerilerini incelediğinde, karşı iddiaları oluşturabilme, onları çürütebilme becerisinin alan bilgisindeki artışa bağlı olduğunu ve süreç boyunca gelişim gösterdiğini tespit etmiştir. Namdar ve Salih (2017), fen bilgisi öğretmen adaylarının karşıt argümanlara dikkat edemediklerini, bu durumun adayların karşıt argüman ve çürütücü üretme gibi üst düzey argümantasyon becerilerine sahip olmamalarından ve argümantasyon sürecinde yetersiz deneyim yaşadıklarından kaynaklandığını ifade etmişlerdir. $\mathrm{Bu}$ süreçte karşıt argüman üretmeyi geliştirici görsel, bilgisayar destekli öğrenme ortamlarına yer verme önerisinde bulunmuştur. Tal ve Kedmi (2006) ise argümantasyona dayalı yapılan öğretim sürecinde onuncu sınıf lise öğrencilerinin karşı argüman kurma becerilerinde ilerleme sağladığını tespit etmişlerdir. Bu karşılaştırma öğrencilerin gerekçe kullanma sayısına, bilimsel bilgi kullanma miktarına, konuları içerme sayısına ve karşı argümanlar ve çürütmelerin sayısına bakılarak yapılmıştır. Yapılan bu çalışmada da benzer şekilde uygulama süreci boyunca öğretmen adaylarının karşıt argüman oluşturma ortalama puanları artmıştır. Ancak bu artış başlangıçtaki savunulan argüman ortalama puanlarınınki kadar yüksek olamamıştır. Jan (2009), grup veya tüm sınıf tartışması gibi bazı etkinliklerin argümantasyon becerisini geliştirmeye yardımcı olduğunu belirtmiştir. Gülhan (2012) çalışmasında, ortaokul sekizinci sınıf öğrencilerinin sosyobilimsel konularda tartışma etkinliğinden önce iddialarda bulunduklarını ancak bu iddialarını desteklemediklerini görmüş ancak grup tartışma yönteminden sonra öğrencilerin iddialarını daha iyi yapılandırdıklarını ve fikirlerini daha güçlü argümanlarla desteklediklerini ortaya çıkarmıştır. Dolayısıyla yapılacak argümantasyon temelli çalışmalarda bireysel etkinlikler yanında grup etkinliklerinin yapılmasının argüman oluşturmayı geliştirdiği düşünülerek grup etkinliklerine önem verilmelidir. Böylece sınıf öğretmeni adaylarının karşıt argüman oluşturma becerileri de istenen seviyede gelişim gösterebilir.

$\mathrm{Bu}$ çalışmada çevre eğitimi dersi argümantasyon temelli öğretim süreci temel alınarak yapılmıştır. Uygulamalarda enerji konusundaki sosyobilimsel özelliği olan senaryolar kullanılmıştır. Bu sayede öğretmen adaylarının hem konu hakkındaki bilgileri hem de argüman oluşturma becerileri artmıştır. Kısaca süreç içerisinde öğretmen adaylarının çevre eğitimi ders konularında edindikleri bilgiler ve sosyobilimsel konuların özelliği olan ikilemli durumların 
muhakemesi argüman oluşturma sürecine katkı sağlamış olabilir. Sosyobilimsel konu temelli çalışmalara bakıldığında, Lin ve Mintenz (2010), sosyobilimsel uygulamaların ortaokul altıncı sınıf öğrencilerinin argümantasyon becerilerini geliştirdiği, iddia, gerekçe, karşıt iddia gibi becerilerinde ise gelişim meydana getirdiği sonucuna ulaşmışlardır. Öztürk (2013) sekizinci sınıf öğrencileri ile yaptığı araştırmasında, sosyobilimsel konu temelli uygulamaların öğrencilerin argüman becerilerinde gelişim meydana getirdiği ve süreç ilerledikçe öğrencilerin daha kaliteli argümanlar ürettikleri sonucuna ulaşmıştır. Zengin, Keçeci ve Kırılmazkaya (2012), sosyobilimsel bir konu olan nükleer santraller konusunda ilköğretim öğrencileri ile yaptıkları deneysel çalışmada ön-son test ortalama puanlar arasında anlamlı farklılık tespit etmişler ve öğrencilerin haftalar ilerledikçe daha kaliteli argümanlar ürettiklerini belirtmişlerdir. Yapılan bu çalışmanın da sosyobilimsel konu temelli olarak yürütülmesi, sınıf öğretmeni adaylarının argüman oluşturma ortalama puanlarını artırabilmiş ve argüman elemanlarını zaman içerisinde daha fazla kullanarak, daha kaliteli argüman oluşturabilmeyi sağlayabilmiştir.

Çalışma sonuçları dikkate alındığında öğretmen adaylarının nitelikli argüman üretebilme becerisini kazanmaları için farklı derslerde bu sürecin bireysel ve grup olarak uygulanması faydalı olabilir. Zeidler ve Sadler (2008) argüman becerisi kazanan öğrencilerin demokratik, katılımcı ve bilgili öğrenciler olmaları gerektiğini ve argümantasyon sürecinin vatandaşlık eğitimi için dahi kullanılabileceğini savunmuştur. Böylece fen eğitimi ile öğrencilerin aktif, bilgili, düşünen, sorumlu ve demokratik katılımcı olmaları sağlanabilir, etik ve ahlaki karar verme becerilerinin geliştirilmesi amaçlanabilir (Kolsto, 2010; Waghid, 2005). Argümantasyon temelli öğretim süreci, ders sürecini geleneksel öğretimin dışarısına çıkarttığı ve öğrencilerin aktif katılımını sağladığı için, düşünme, tartışma, etkileşime sokma, sosyalleşme gibi özellikler de içermektedir. Sınıf öğretmeni adaylarına grup içerisinde argümanlarını savunmalarının yanı sıra, argümanlarını güçlendirme, argümanın farkına varma, argümanında farklı bakış açısı kazanma, argümanını değiştirme ya da karşıt argümanlara saygı duyma gibi özellikler kazandırabilir. Öğretmen adaylarının argümantasyon temelli öğretim sürecine aşina olmaları için argümantasyonun farklı derslerde de uygulanması uygun olacaktır. Argümantasyon temelli öğretim öğretmen adaylarının meslek hayatlarına hazırlık ve pedagojik becerilerinin gelişmesi noktasında da katkı sağlayacaktır. Çevre Eğitimi kapsamında enerji konusunun yanı sıra çevre farkındalığını arttırıcı farklı sosyobilimsel konular (klonlama, GDO, gen tedavisi, organ bağışı vb.) farklı araştırmacılarca seçilebilir ve bu senaryolarla da süreç tasarlanabilir. 
Öğretmeni Adaylarının Argüman Oluşturabilmelerine Etkisi

\section{Kaynakça}

Acar Ö. (2009). Argumentation skills and conceptual knowledge of undergraduate students in a physics by inquiry class. Doctoral dissertation, Ohio State University, Colombus

Aktaş, T. (2017). Argümana dayal sorgulama ögrretiminin 7. Sinlf öğrencilerinin kuvvet ve enerji ünitesindeki akademik başarlarına ve argümantasyon seviyelerine etkisi. Yüksek lisans tezi, Marmara Üniversitesi Eğitim Bilimleri Enstitüsü, İstanbul

Aldağ, H. (2006). Toulmin tartışma modeli. Ç.Ü. Sosyal Bilimler Enstitüsü Dergisi, 15(1), 13-34.

Alexander, P. A., Kulikowich, J. M., \& Schulze, S. K. (1994). The influence of topic knowledge, domain knowledge, and interest on the comprehension of scientific exposition. Learning and Individual Differences, 6 (4), 379-397.

Andrews, R. (2010). Argumentation in higher education improving practice through theory and research. Newyork and London: Routledge.

Aslan, F. (2015). Yenilenebilir enerji kaynaklarının fen eğitimi açısından önemi ve bu bağlamda gelistirilen rüzgâr türbini materyalinin fen ve teknoloji dersi kazanımları üzerindeki etkisi. Yüksek lisans tezi, Fırat Üniversitesi Eğitim Bilimleri Enstitüsü, Elazığ.

Babacan, M. A. (2017). Sosyobilimsel konulardaki etkinliklerin yedinci sınıf öğrencilerinin eleştirel düsünme becerilerine etkisi. Yüksek Lisans Tezi, Ömer Halisdemir Üniversitesi Eğitim Bilimleri Enstitüsü, Niğde

Başkale, H. (2016). Nitel araştırmalarda geçerlik, güvenirlik ve örneklem büyüklüğünün belirlenmesi. Dokuz Eylül Üniversitesi Hemşirelik Fakültesi Elektronik Dergisi, 9(1), 23-28.

Creswell, J. W. (2013). Araştırma deseni (S. B. Demir, Çev.). Ankara: Eğiten Kitap

Çapık, C. (2014). İstatistiksel güç analizi ve hemşirelik araştırmalarında kullanımı: Temel bilgiler. Anadolu Hemşirelik ve Sağlık Bilimleri Dergisi, 17(4), 268-274.

Çetin, P. S., Kutluca, A. Y. ve Kaya, E. (2013). Öğrencilerin argümantasyon kalitelerinin incelenmesi. Fen Bilimleri Öğretimi Dergisi, 2(1), 56-66.

Çınar, D. (2013). Argümantasyon temelli fen ögretiminin 5. Sinıf ögrrencilerinin öğrenme ürünlerine etkisi. Doktora tezi, Necmettin Erbakan Üniversitesi Eğitim Bilimleri Enstitüsü, Konya.

Çınar, B. T. (2016). Argümantasyona dayalı öğretimin ilköğretim öğrencilerinin başarlları kavramsal anlamaları ve eleştirel düşünme becerileri üzerine etkisi: Yaşamımızdaki Elektrik ünitesi. Doktora tezi, Marmara Üniversitesi Eğitim Bilimleri Enstitüsü, İstanbul.

Demirel, T. (2017). Argümantasyon yöntemi destekli artırllmış gerçeklik uygulamalarının akademik başarl, eleştirel düşünme becerisi, fen ve teknoloji dersine yönelik güdülenme ve argümantasyon becerisi üzerindeki etkisinin incelenmesi. Doktora tezi, Çukurova Üniversitesi Sosyal Bilimler Enstitüsü Eğitim Bilimleri Anabilim Dalı, Adana

Dolan, T. J., Nichols, B. H. \& Zeidler, D. L. (2009). Using socioscientific issues in primary classrooms. Journal of Elementary Science Education, 21 (3), 1-12.

Duschl, R. A. ve Osborne, J. (2002). Supporting and promoting argumentation discourse in science education, Studies in Science Education, 38(1), 39-72.

Erduran, S., Simon, S., \& Osborne, J. (2004). TAPping into argumentation: Developments in the application of Toulmin"s argument pattern for studying science discourse. Science Education, 88(6), 915-933.

Fraenkal, J. R., Wallen, N. E. \& Hyun, H. H. (2012). How to design and evaluate research in education (8th edn). New York: McGraw-Hill.

Furtak, E. M. (2006). The problem with answers: An exploration of guided scientific inquiry teaching. Science Education, 90(3), 453-467. 
Gray, D.S. \& Bryce, T. (2006). Socio-scientific issues in science education: 1mplications for the professional development of teachers. Cambridge Journal of Education, 36(2), 171-192.

Gülhan, F. (2012). Sosyo-bilimsel konularda bilimsel tartışmanın 8. Sinıf öğrencilerinin fen okuryazarlı̆̆l, bilimsel tartışmaya eğilim, karar verme becerileri ve bilim-toplum sorunlarına duyarlılıklarına etkisinin araştırılması. Yüksek lisans tezi, Marmara Üniversitesi Eğitim Bilimleri Enstitüsü, İstanbul.

Güzel, B. Y., Erduran, S. ve Ardaç, D. (2009). Aday kimya öğretmenlerinin kimya derslerinde bilimsel tartışma (argümantasyon) tekniğini kullanımları. Boğaziçi Üniversitesi Eğitim Dergisi, 26(2), 3349.

Hasançebi, F. (2014). Argümantasyon tabanlı bilim öğrenme yaklaşımının (atbö) öğrencilerin fen başarıları, argüman oluşturma becerileri ve bireysel gelişimleri üzerine etkisi. Doktora tezi, Atatürk Üniversitesi Eğitim Bilimleri Enstitüsü, Erzurum

Huberman, M. (1994). Gentle teaching in a violent society. Educational Horizon, 72(3), 131-135.

İpekoğlu, H. Y., Üçgül, İ. ve Yakut, G. (2014). Yenilenebilir enerji algısı anketi: Güvenirlik ve geçerliği. Süleyman Demirel Üniversitesi Yekarum E-Dergi, 2(3), 20-26.

Jan, M. (2009). Desiging an augmented reality game-based curriculum for argumentation. Doctoral Dissertation, University of Wisconsin, USA

Karakaya, E. (2015). Bilimsel bilginin doğasını anlama ve sosyo-bilimsel konularda akıl yürütme. Yüksek lisans tezi, Marmara Üniversitesi Eğitim Bilimleri Enstitüsü, İstanbul.

Khishfe, R. (2012). Relationship between nature of science understandings and argumentation skills: A role for counterargument and contextual factors. Journal of Research in Science Teaching, 49(4), 489-514.

Kolsto, S. O. (2010). Patterns in students' argumentation confronted with a riskfocused socio-scientific issue. International Journal of Science Education, 28(14), 1689-1716.

Lazarou, D. (2009). Learning to tap: An effort to scaffold students' argumentation in science. In G. Cakmakci \& M. F. Taşar (Eds.) Contemporary Science Education Research: Scientific Literacy And Social Aspects Of Science (pp: 43-50), Ankara, Turkey: Pegem Akademi.

Lin, S. S, \& Mintzes, J. J. (2010). Learning argumentation skills through instruction in socioscientific issues: The effect of ability level. International Journal of Science and Mathematics Education, 8, 993-1017.

Namdar, B. ve Salih, E. (2017). Fen bilgisi öğretmen adaylarının teknoloji destekli argümantasyona yönelik görüşleri. Abant İzzet Baysal Üniversitesi Ĕgitim Fakültesi Dergisi, 17(3), 1384-1410.

Özsoy, S. \& Özsoy, G. (2013). Eğitim araştırmalarında etki büyüklüğü raporlanması. İlköğretim Online, 12(2), 334-346.

Öztürk, A. (2013). Sosyo-bilimsel konularla argümantasyon becerisi ve insan haklarına karşı tutum geliştirmeye yönelik bir eylem araştırması. Doktora tezi, Çukurova Üniversitesi Sosyal Bilimler Enstitüsü, Adana

Roberts, P., Priest, H., \& Traynor, M. (2006). Reliability and validity in research. Nursing Standard, 20(44), 41-45.

Sadler, T. D. (2003). Informal reasoning regarding ssi: the influence of morality and content knowledge. Doctoral dissertation, University of South Florida.

Schmoker, M. \& Graff, G. (2011). More argument, fewer standards. Education Week, 30(28), 31-33.

Şahin, D. (2014). Dördüncü ve beşinci sınıf öğrencilerinin argüman yapıları. Doktora tezi, Gazi Üniversitesi Eğitim Bilimleri Enstitüsü, Ankara.

Tal, T. \& Kedmi, Y. (2006). Teaching socioscientific issues: Classroom culture and students' performances. Cultural Studies of Science Education, 1(4), 615-644. 
Çevre-Enerji Konularına Yönelik Gerçekleştirilen Argümantasyon Temelli Öğretimin Sınıf

Öğretmeni Adaylarının Argüman Oluşturabilmelerine Etkisi

Topçu, M. S. (2015). Sosyobilimsel konular ve öğretimi. Ankara: Pagem Akademi.

Torun, F. (2015). Sosyal bilgiler dersinde argümantasyon temelli ögretim ve karar verme becerisi arasındaki ilişki düzeyi. Doktora tezi, Gazi Üniversitesi Eğitim Bilimleri Enstitüsü, Ankara.

Toulmin, S. (1958). The uses of argument. Cambridge: Cambridge University Press

Waghid, Y. (2005). Action as educational virtue: toward a different understanding of democratic citizeship ecucation. Educational Theory, 55(3), 323-243.

Zeidler, D. L. \& Sadler, T. D. (2008). The rol of moral reasoning in argumentation: Conscience character and care. In S.Erduran \& M.P. Jimenez-Aleixandre (Eds), Argumentation in science education: Perspectives from classroom-based research (201-216). Dordrecht Nerherlands: Springer Press

Zengin, F., Keçeci, G. ve Kırılmazkaya, G. (2012). İlköğretim öğrencilerinin nükleer enerji sosyobilimsel konusu online argümantasyon yöntemi ile öğrenmesi. New World Sciences Academy - Education Sciences, 7(2), 647-654. 


\section{Extended Abstract}

\section{Introduction}

In the schools, the students will be able to interpret the effects of scientific and technological developments on the environment and society in a scientific framework with socio-scientific based teaching activities. A method in which students can discuss socio-scientific issues in this scientific framework is the process of producing arguments. The argument is defined as claims, data, rationales and supporters contributing to a discussion process; it is characterized as expressions put forward to reveal the strengths of a situation or subject and to convince others to this idea. While via using the Toulmin Argument Model in learning-teaching environments, theory and learning models are brought together in a special field, students express themselves by using claims, data or real-world experiences. The method of argumentation is an important teaching method for the students in terms of teaching the subjects in a more interesting way, remembering the knowledge learned, learning the information more permanently, developing the analysis and synthesis. This can only be achieved by gaining experience in the argumentation process and increasing the quality of the argument using the components of the Toulmin Argument Model. At this point, it was considered important by the researchers that the primary school teacher candidates, who will introduce the students to the science subjects for the first time in the future, to gain experience on the argumentation-based teaching process. In this context, the aim of this study is to investigate the effect of argumentation-based instruction on environmental-energy subjects on the argument-making skills of primary school teacher candidates.

\section{Method}

In the study, a holistic multiple state pattern was used. At the end of the argumentation-based teaching process, individual and group arguments of the primary school teacher candidates on scenarios of environment-energy were analyzed and the data were interpreted. The arguments related to the scenarios were obtained in writing in the classroom environment and these obtained documents were analyzed. 44 teacher candidates in their second year at Primary School Teaching Department of the Basic Education Department at the Faculty of Education of a university in the Central Anatolia Region were included in the study group. In order to determine the argumentation skills of the primary school teacher candidates, socio-scientific scenarios were prepared by the researchers on environmental-energy issues, energy sources and types, production and use of energy, and the real-life problems that examined the environmentenergy-development relationship. Document analysis was used in the analysis of the data and the arguments of the candidates for each scenario as individual and group were evaluated based on the Toulmin Argument Model. Argument Structure Scoring Key was used in the calculation of the average score of primary school teacher candidates; Argumentation Rating Scale was used to determine the argument levels.

\section{Results and Discussion}

As a result of the research, it was detected that during the argumentation-based teaching process, there was an increase in the primary school teacher candidates' individual, group, individual counter argument and group counter argument average scores, from the first activity 
to the last activity, the difference between the mean scores was statistically significant $(\mathrm{p}<0.05)$, and the effect size of the difference between the individual and individual counter argument average scores (Cohen's $f$ ) was also a wide impact. This increase in points means that in the process, primary school teacher candidates use more argument components, so they produce more qualified arguments.

In the research, the argument levels of the primary school teacher candidates showed progress from the first week to the last week from the low level to the middle and high levels. Therefore, candidates tend to use the weak / strong cons as the process proceeds, increasing the level of arguments. Likewise, it was revealed with scientific studies that fifth grade students understand the argumentation process over time and can create high-level arguments (Cinar, 2013), and argumentation quality of high school ninth grade students was increased according to the process, as a result of the argumentation process (Çetin, Kutluca \& Kaya, 2013). In the end of this study, it was observed that the primary school teacher candidates increased their argument levels in 10 weeks and they were able to create a higher quality argument.

It was concluded that the progress in the individual counter arguments formed by the primary school teacher candidates was not sufficient compared to the others. This is also related to the low average counter argument scores. Candidates are low in both the average score and the level of creating counter arguments. While preserving their own arguments, teacher candidates used more argument dimension with the motivation to persuade their group friends. The fact that there is no obligation to persuade in generating counter arguments may be the reason for the teacher candidates to be inadequate.

This study is based on the argumentation-based teaching process of the environmental education course. In the implementations, the scenarios with the socio-scientific features on the subject of energy were used. In this way, both the knowledge of teacher candidates about the subject, and their ability to create arguments have increased. Briefly, the knowledge gained by teacher candidates about environmental education course subjects and the dilemma of binary situations which are characteristic of socio-scientific issues may have contributed to the process of argument formation. On the basis of socio-scientific studies, Lin and Mintenz (2010) conclude that socio-scientific practices develop the argumentation skills of the sixth grade students in the middle school and that they lead to the development of their skills such as arguments, arguments and opposing arguments.

\section{Suggestions}

Considering the results of the study, it may be useful to implement this process individually and as a group in different courses in order teacher candidates to gain the ability to produce qualified arguments. Since the argumentation-based teaching process takes the course process out of traditional education and enables the active participation of the students, it also includes features such as thinking, discussing, interacting, and socializing. It will be appropriate to implement the argumentation in different courses to enable teacher candidates to be familiar with the argumentation-based teaching process. 